\title{
Interactive effects of salt and fat reduction on composition, rheology and functional properties of mozzarella-style cheese
}

\author{
S. Henneberry ${ }^{1}$ - M. G. Wilkinson ${ }^{2}$. \\ K. N. Kilcawley ${ }^{1}$ • P. M. Kelly ${ }^{1}$ - T. P. Guinee ${ }^{1}$
}

Received: 3 February 2015 / Revised: 10 April 2015 / Accepted: 14 April 2015 /

Published online: 22 May 2015

C) INRA and Springer-Verlag France 2015

\begin{abstract}
Owing to the risks associated with excessive dietary intake of fat and sodium, there is an increased consumer demand for food products, including cheese, with reduced fat and salt content. Research to date has focused mainly on the separate effects of reducing fat and salt. The primary objective of this study was to evaluate the combined effects of reducing fat from $\sim 22 \%$ to $11 \%$ and salt from $\sim 1.7 \%$ to $1.0 \%$, on the composition, rheology and melting properties of mozzarella cheese. A secondary objective was to investigate the effect of reducing the calcium content of the reduced-fat, reduced-salt cheese as a means of improving its properties. Reducing fat and salt content led to higher levels of protein and moisture, lower contents of moisture-in-non-fat substances, fat-in-dry matter and salt-inmoisture. These changes coincided with lower water binding capacity, lower primary proteolysis and increased hardness and chewiness in the unheated cheese, and with a lower flow and higher work to extend (EW) the heated cheese. Lowering the calcium content of the reduced-fat reduced-salt cheese increased the levels of moisture and moisture-in-non-fatsubstances, and reduced the protein content and the calcium-to-casein ratio; simultaneously, the unheated cheese had a higher water binding capacity, a reduced hardness and chewiness, while the heated cheese had higher flowability and a lower EW compared to the reduced-fat, reduced-salt cheese. Despite the mitigating effects of calcium reduction, the reduced-fat, reduced-salt, lower-calcium cheese was, nevertheless, firmer, harder, more cohesive and chewy, flowed less and had a higher EW than the full-fat, full-salt cheese.
\end{abstract}

This paper is part of the Special issue dedicated to the 9th International Cheese Symposium held in Cork, Ireland and organized by Teagasc in collaboration with University College Cork and INRA, 12th \& 13th November 2014.

T. P. Guinee

Tim.Guinee@teagasc.ie

1 Teagasc Food Research Centre Moorepark, Fermoy, Co. Cork, Ireland

2 School of Life Sciences, University of Limerick, Co. Limerick, Ireland 
Keywords Mozzarella $\cdot$ Fat $\cdot$ Salt $\cdot$ Calcium $\cdot$ Properties

\section{Introduction}

Pizza consumption continues to expand globally, especially in the US where sales value was estimated at US \$38 billion in 2014 (Nickle and Pehrsson 2013; Hynum 2014; Rhodes et al. 2014). Simultaneously, the production of mozzarella, the principal cheese used in pizza, continues to expand, for example by $1.3 \%$ per annum in the USA between 2010 and 2014, from 1.55 to $1.62 \mathrm{M}$ tonnes (Statista 2015). Nevertheless, pizza at high consumption rates can contribute significantly to dietary fat and sodium, especially in the youth (Moshfegh et al. 2012; Drewnowski and Rehm 2013; Powell et al. 2015). Excessive intakes of fat, saturated fat and sodium are undesirable because the associated health risks, such as obesity, hypertension, heart attack, stroke, cancer and diabetes (He and MacGregor 2009; Moshfegh et al. 2012). In response, there is an increasing demand for cheeses with reduced levels of salt and fat.

Consequently, there has been a significant focus on the separate effects of reducing fat (Rudan et al. 1999; van Hekken et al. 2007) and salt (Paulson et al. 1998; Ma et al. 2013) on the quality of mozzarella cheese. Generally, fat reduction is associated with an increase in rigidity, elasticity and hardness and a loss of meltability. Various approaches have been used to improve the quality of reduced-fat mozzarella, including a reduction in the calcium content of the cheese (Metzger et al. 2001) and homogenization or microfluidization of milk or cream (Tunick et al. 1993; Rudan et al. 1998; van Hekken et al. 2007). While extensive research has considered the effects of altering salt content of cheddar cheese (Rulikowska et al. 2013), comparatively little information is available on the influence of salt on the quality of mozzarella. Unsalted mozzarella was found to have lower water-holding capacity and lower heat-induced flowability than the corresponding salted cheese $(\sim 1-2 \%$ NaCl; Guo et al. 1997; Paulson et al. 1998).

The current study on cheese was undertaken as a work package within the FP7 EU funded project 'novel processing approaches for the development of food products low in fat, salt and sugar reduced' (acronym 'PLEASURE'). An overall ambitious goal was to achieve inter alia comparable sensory properties in the 'reduced' fat and salt cheeses with equivalent products of 'normal' composition, thus setting the scene for deployment of novel technological adaptations and textural restructuring where needed. This translated into the experimental objectives of the present study, i.e. to investigate the effects of the simultaneous reduction of fat and salt, from $22 \%$ to $11 \%$ and from $1.7 \%$ to $1.0 \%$, respectively, on the compositional, biochemical and functional properties of mozzarella-style cheese, and to explore the effect of reducing the calcium content, and hence the degree of calcium-induced cross-linking of casein, as a means of normalizing the characteristics of the reduced-fat, reduced-salt cheese.

\section{Materials and methods}

\subsection{Cheese manufacture}

Mid-lactation milk was obtained on three occasions over a 6-week period from the autumn-calving Friesian herd at the Animal and Grassland Research and Innovation Centre, Teagasc, Moorepark. The milk was standardized to the required protein-to-fat 
ratios for the control (full-fat; 0.94) and reduced-fat (3.36) cheeses, pasteurised at $72{ }^{\circ} \mathrm{C}$ for $15 \mathrm{~s}$, cooled to $36{ }^{\circ} \mathrm{C}$, and pumped into jacketed, cylindrical, stainless steel 500-L vats with automated variable-speed cutting and stirring (APV Schweiz AG, CH-3076 Worb 1, Switzerland).

The milk was inoculated with frozen cultures Streptococcus thermophilus (TH4) and Lactobacillus helveticus (LHBO2) at weight a ratio of 2:1 and at a level recommended by the supplier (Chr. Hansen, Little Island, Cork, Ireland). After a 40-min inoculation period, chymosin (single strength Chy-Max ${ }^{\circledR}$ plus, 200 IMCU; Chr. Hansen, Hoersholm, Denmark) was diluted 1 in 10 with distilled water and added at level of 0.14 mL. $\mathrm{kg}^{-1}$ milk based on a protein level of $3.16 \mathrm{~g} .100 \mathrm{~g}^{-1}$. Following gelation, the gels were cut at a similar strength $\left(\mathrm{G}^{\prime}, 40 \mathrm{~Pa}\right)$ measured using low amplitude strain oscillation rheometry (Guinee et al. 2000), healed for $10 \mathrm{~min}$, and the curd-whey mixture was cooked at a rate of $0.25{ }^{\circ} \mathrm{C} \cdot \mathrm{min}^{-1}$ to a scald temperature $42{ }^{\circ} \mathrm{C}$ for the full-fat cheese and $38^{\circ} \mathrm{C}$ for the reducedfat cheese. The whey was drained at a $\mathrm{pH}$ of 6.0 for the full-fat and 6.1 for the reduced-fat cheese and the drained curds formed into a consolidated mass which was cut into slabs. The slabs were piled at $\mathrm{pH} 5.6$ and milled at $\mathrm{pH} 5.1$. Subsequently, the curds were salted at a rate of 4.21 and $2.06(\% w / w)$ for the full-salt and reduced-salt variants of the full-fat (FFFS and FFRS) and reduced-fat (RFFS and RFRS) cheeses. The salted curds were held 20 min while turning at 5-min intervals to ensure uniform salt distribution. The curds were then transferred to the stretching unit (Automatic Stretching Machine, Model d; CMT, S. Lorenzo di Peveragno $\mathrm{CN}$, Italy) and plasticized using water at $78-80{ }^{\circ} \mathrm{C}$ at a water: curd ratio of $\sim 1.4$, as described by Guinee et al. (2000). The hot curd $\left(58^{\circ} \mathrm{C}\right)$ was moulded into rectangular 2.3-kg blocks, which were cooled by holding the blocks in a dilute brine solution $(10 \% w / w \mathrm{NaCl} ; 0.2 \% \mathrm{w} / \mathrm{w} \mathrm{Ca})$ at $\sim-3$ to $2{ }^{\circ} \mathrm{C}$ for $30 \mathrm{~min}$, allowed to surface dry at room temperature for $20 \mathrm{~min}$, vacuumed packed and stored at $4{ }^{\circ} \mathrm{C}$ for 75 days.

The method for manufacture the reduced-fat, low-calcium full-salt and reduced cheeses (RFFSLCa, RFRSLCa) was the same as the reduced-fat full salt and reduced-salted cheese, except for the following differences: the milk was acidified to $\mathrm{pH} 5.7$ at $29{ }^{\circ} \mathrm{C}$ by adding the required quantity of diluted lactic acid $11 \% \mathrm{w} / \mathrm{v}$, the whey was drained at $\mathrm{pH} 5.6$ at $\sim 35 \mathrm{~min}$ after scalding to $38^{\circ} \mathrm{C}$, the curds were milled and salted at 5.65 and $2.24 \%$, respectively, for the full-salt (RFFSLCa) and reduced-salt (RFRSLCa) variants. Preliminary studies were undertaken to establish the required salting levels for the different cheeses.

\subsection{Sampling of cheese}

Cheeses were sampled for composition at 7 day, for $\mathrm{pH}$, water-soluble $\mathrm{N}$ (WSN), expressible serum, firmness, texture profile analysis and heat-induced-flow at 1, 7, 15, 35, 50 and 75 days. The work to extend (stretch) the hot molten cheese (EW) was measured at 35, 50 and 75 days only, due to unavailability of measuring equipment at earlier times.

\subsection{Analysis of cheese}

\subsubsection{Composition}

Cheese was cut into cubes $\left(2.5 \mathrm{~cm}^{3}\right)$, shredded in a Hallde RG-350 machine (AB Hallde Maskiner, Kista, Sweden) using the raw food grating disc (K), and grated to 
particle size of $<1 \mathrm{~mm}$, in a Braun blender (34209 Melsungen, Germany). The grated cheese was analysed in triplicate at 7 days for moisture, fat, total protein, ash, calcium, phosphorous and salt using IDF standard methods (Guinee et al. 2000). The $\mathrm{pH}$ was measured at each of the sampling points using a cheese slurry prepared by macerating a blend of the grated cheese $(20 \mathrm{~g})$ and heated $\left(40{ }^{\circ} \mathrm{C}\right)$ distilled water (12 g).

\subsubsection{Proteolysis}

A water-soluble extract of the cheese was prepared from a slurry of cheese and water at a weight ratio of 1:2 (Fenelon and Guinee 2000), and a 3-mL sample of the filtrate was analysed for WSN using macro-Kjeldahl method (IDF 1993).

Urea-polyacrylamide gel electrophoresis (urea-PAGE) was performed on a PROTEANs II xi cell vertical slab gel unit (Bio-Rad Laboratories Ltd., Hemel Hempstead, Herts, UK), using a separating and stacking gel system, as described by Rynne et al. (2004). The sample buffer ( $\mathrm{pH} 8.7$ ) was prepared by dissolving $0.75 \mathrm{~g}$ Tris (hydroxymethyl)- methylamine, $49 \mathrm{~g}$ urea, $0.7 \mathrm{~mL}$ mercaptoethanol and $0.15 \mathrm{~g}$ bromophenol blue in distilled $\mathrm{H}_{2} 0$, made up to a final volume of $100 \mathrm{~mL}$. Cheeses were dissolved based on a defined quantity of protein (4.25 g. $\mathrm{L}^{-1}$ sample buffer) and also on a defined quantity of cheese (16 g.L $\mathrm{L}^{-1}$ sample buffer). The dissolved samples were incubated at $55{ }^{\circ} \mathrm{C}$ for $60 \mathrm{~min}$ and filtered through glass wool to remove fat deposits. The gels ( $1 \mathrm{~mm}$ thick) were pre-run at $280 \mathrm{~V}$ for $40 \mathrm{~min}$ prior to sample loading. Gels were run at $280 \mathrm{~V}$ for $30 \mathrm{~min}$, for the stacking gel, and at $300 \mathrm{~V}$ for the separating gel until the tracking dye was approximately $1 \mathrm{~cm}$ from the end of the plates. Gels were stained in Coomassie Blue G250, destained in acetic acid $(10 \%) /$ methanol $(25 \%)$ mixture, and rinsed in distilled water.

\subsubsection{Texture profile analysis and firmness}

Six cube-shaped samples $(2.5 \mathrm{~cm})$ were cut from each cheese, wrapped tightly in tin foil and stored refrigerated $\left(4{ }^{\circ} \mathrm{C}\right)$ overnight. Each cube was taken from the refrigerator and immediately compressed, in a direction perpendicular to the direction of fibre orientation, to $60 \%$ of its original height in two consecutive bites at a rate of $60 \mathrm{~mm} \cdot \mathrm{min}^{-1}$ on a TAHDi texture profile analyser (TPA) (Stable Micro Systems, Goldalming, Surrey, England) at room temperature. A typical TPA (force/ distance) profile is shown in Fig. 1. The following parameters were calculated from the TPA profile: hardness, defined as the maximum force recorded in bite 1 (height H1); cohesiveness, ratio of area during compression in bite 2 to area in bite 1 (A2/A1); adhesiveness, area of the negative peak formed when the cross-head (plunger) is withdrawn from the sample after the first bite (A3); springiness, as the ratio of the distance travelled by the plunger in bite 2 (C) to the distance travelled during bite $1(\mathrm{~B})$; and chewiness, product of hardness $\times$ cohesiveness $\times$ springiness $(\mathrm{H} 1 \times \mathrm{A} 2 / \mathrm{A} 1 \times \mathrm{C} / \mathrm{B})$.

Firmness was measured in a single-bite compression test, in which each cheese cube was compressed to $30 \%$ of its original height. None of the cheese samples fractured during compression; firmness, was calculated as the force (height) at full compression. 


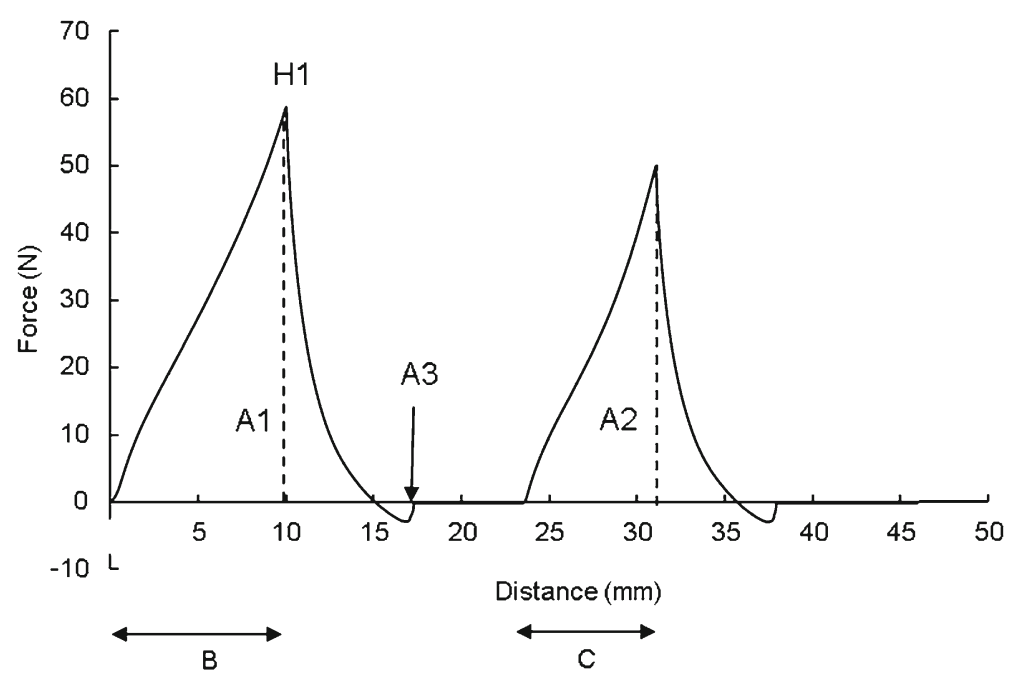

Fig. 1 A typical force distance profile by TPA on compressing a cube-shaped sample of mozzarella style to $40 \%$ of its original height cheese at a rate of $60 \mathrm{~mm}$.min at $8^{\circ} \mathrm{C} . \mathrm{Al}$ refers to area under the force-distance curve in compression (bite) $1, A 2$ to the area under the curve in bite 2, $A 3$ to the area of the negative force on decompressing after bite $1, B$ to the compression distance in bite 1 , and $C$ to the compression distance in bite 2

\subsubsection{Non-expressible serum}

Levels of expressible cheese serum (ES) expressed during centrifugation at $12,500 \times g$ for $75 \mathrm{~min}$ at $25^{\circ} \mathrm{C}$, were measured as described by (Guinee et al. 2002). Expressed serum and fat were collected in a Duran bottle (Duran Group GmbH, Mainz, Germany) and stored at $4{ }^{\circ} \mathrm{C}$ until the fat layer had solidified. The fat layer was punctured and the sub-natant serum was then collected and weighed to give the level of expressible serum. The level of non-expressible serum was then calculated by subtracting the weight of expressible serum per $100 \mathrm{~g}$ cheese from the percentage moisture, and expressing as gramme per gramme of protein (NESP g.g protein ${ }^{-1}$ ).

\subsubsection{Functionality on heated cheese}

Heat-induced melting was measured by expressing a change in dimension (e.g. diameter, length) as a \% of the original dimension on heating using (1) a modified Schreiber method and (2) a modified Olson and Price method (Guinee and O'Callaghan 2013). The former is indicative of the melting behaviour of cheese when exposed as a toping (e.g. on pizza) during oven heating, and the latter when the cheese is covered, or largely covered, during cooking (e.g. as a cheese slice in hamburger).

The work required to extend the molten cheese (EW) was measured using uniaxial extension on a TA-HDi Texture Analyser (Fig. 2). Grated cheese (60 g) was filled into a plastic container $(9 \mathrm{~cm} \times 5.5 \mathrm{~cm} \times 4 \mathrm{~cm})$ containing a comb, placed in a microwave oven (Whirlpool MW201, Fonthill Industrial estate, Dublin 22, Ireland) set at $750 \mathrm{~W}$, and heated for $55 \mathrm{~s}$ to 90 to $95{ }^{\circ} \mathrm{C}$, to mimic cooking temperatures on a pizza pie. The plastic container with the molten cheese was immediately placed in the measuring cell 


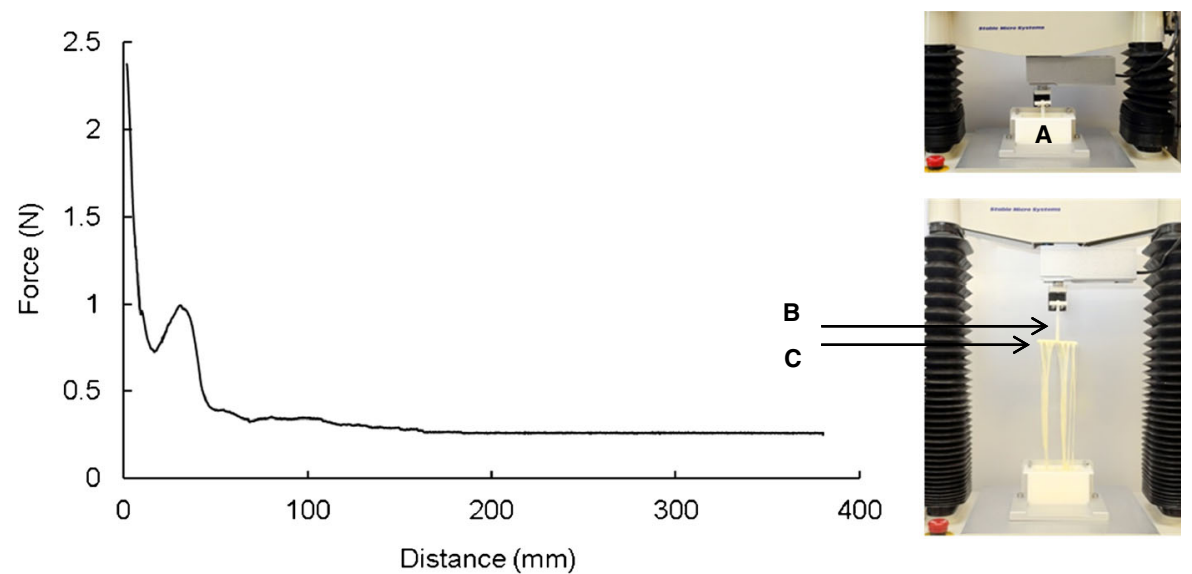

Fig. 2 A typical force-distance curve obtained on extension of hot molten cheese $\left(94^{\circ} \mathrm{C}\right)$ by $380 \mathrm{~mm}$ at a rate of $10 \mathrm{~mm} . \mathrm{s}^{-1}$. The top inset shows the plastic container $(A)$ with the extension device consisting of a shaft $(B)$ that connects to the cross-head of the TA-HDi texture analyser and a comb $(C)$ embedded in the molten cheese, and the bottom inset, the molten cheese undergoing uniaxial extension

of the TAHDi texture profile analyser. The comb was attached to the cross-head, which was programmed to pull the comb, and thereby extend the molten cheese, to a distance of $380 \mathrm{~mm}$ at a rate $1 \mathrm{~cm} . \mathrm{s}^{-1}$. The temperature, as measured using a non-contact infrared thermometer (Optex Thermo-Hunter PT-3S; Graham and White Instruments Ltd, St Albans, Hertsfordshire, UK), decreased from $\sim 90{ }^{\circ} \mathrm{C}$ for the molten cheese mass on removal from the oven to $\sim 35-45{ }^{\circ} \mathrm{C}$ of the strings at maximum extension. Using the resultant force-distance curve, the $\mathrm{EW}$ (in millijoule), defined as the force (in newton) by distance (in millimetre), was calculated as the area beneath the curve.

\subsection{Statistical analysis}

Three replicate cheesemaking trials were undertaken, each consisting of six treatment cheeses (FFFS, FFRS, RFFS, RFRS, RFFSLC, RFRSLC) varying in fat, salt and calcium content. A randomised complete block design applied to the six treatments and three blocks (replicate trials) was used for analysis of the response variables relating to cheese composition at 7 days, and, in some cases, to compare different treatments after a given ripening time. Analysis of variance (ANOVA) was undertaken using SAS version 9.3 (SAS Institute 2004). The level of significance was established at $P<0.05$. Tukey's multiple-comparison test was used for paired comparison of treatment means and the level of significance was determined at $P<0.05$.

A split plot design was utilised to measure the effects of treatment, maturation time and the interaction thereof on the response variables as measured at specific intervals throughout ripening. Analysis of variance for the split plot design was carried out using a general linear model (GLM) procedure of SAS 9.3 (SAS Institute 2004). Differences of statistical significance $(P<0.05)$ were established using Fisher's least significant difference. 


\section{Results}

\subsection{Cheese composition}

The gross compositions of the treatment cheese are shown in Table 1. The composition of FFFS complied with the definition of LMPS mozzarella as specified by the FDA (CFR 2014) and is similar to that reported previously for commercial mozzarella (Guinee et al. 2000). Based on the specification for low-moisture part skim mozzarella ( $30 \leq$ fat-in-dry matter $<45 \mathrm{~g} .100 \mathrm{~g}^{-1} ; 45<$ moisture $\left.\leq 52 \mathrm{~g} .100 \mathrm{~g}^{-1}\right)$, the fat content based on the median fat-in-dry-matter (FDM) value $\left(37.5 \mathrm{~g} .100 \mathrm{~g}^{-1}\right.$ cheese $)$ at the minimum and maximum moisture levels are 18.0 and $20.6 \mathrm{~g} .100 \mathrm{~g}^{-1}$, respectively. EU legislation specifies a $30 \%$ reduction in fat content for compliance to the term reduced-fat (EU Regulation EC No 1924 2006). All the experimental reduced-fat cheeses, both full-salt and reduced-salt, had fat levels $<12 \mathrm{~g} .100 \mathrm{~g}^{-1}$, and can therefore, be classified as reduced fat.

Reducing the fat content of the full-salt and reduced-salt cheeses resulted in significant increases in moisture and protein, and decreases in FDM and moisture-in-non-fat-

Table 1 Effect of reducing salt, fat and calcium on 7-day-old mozzarella cheese

\begin{tabular}{lcccccc}
\hline Composition & FFFS & FFRS & RFFS & RFRS & RFFSLCa & RFRSLCa \\
\hline Moisture $(\%, w / w)$ & $47.6^{\mathrm{aB}}$ & $48.0^{\mathrm{aB}}$ & $50.4^{\mathrm{aAy}}$ & $50.1^{\mathrm{aAy}}$ & $56.7^{\mathrm{ax}}$ & $55.8^{\mathrm{ax}}$ \\
Protein $(\%, w / w)$ & $25.4^{\mathrm{aB}}$ & $23.4^{\mathrm{bB}}$ & $32.1^{\mathrm{aAx}}$ & $32.7^{\mathrm{aAx}}$ & $28.2^{\mathrm{ay}}$ & $29.4^{\mathrm{ay}}$ \\
Fat $(\%, w / w)$ & $21.5^{\mathrm{bA}}$ & $23.1^{\mathrm{aA}}$ & $11.4^{\mathrm{aBx}}$ & $11.0^{\mathrm{aBx}}$ & $9.0^{\mathrm{ay}}$ & $10.6^{\mathrm{ax}}$ \\
Salt $(\%, w / w)$ & $1.61^{\mathrm{aA}}$ & $1.03^{\mathrm{bB}}$ & $1.78^{\mathrm{aAx}}$ & $1.13^{\mathrm{bAx}}$ & $1.77^{\mathrm{ax}}$ & $0.94^{\mathrm{bx}}$ \\
$\mathrm{Ca}\left(\mathrm{mg} .100 \mathrm{~g}^{-1}\right)$ & $761^{\mathrm{aA}}$ & $655^{\mathrm{aB}}$ & $942^{\mathrm{aAx}}$ & $1009^{\mathrm{aAx}}$ & $551^{\mathrm{ay}}$ & $506^{\mathrm{ay}}$ \\
Ca $\left(\mathrm{mg} \cdot \mathrm{g}^{-1}\right.$ protein $)$ & $30.0^{\mathrm{aA}}$ & $28.0^{\mathrm{aA}}$ & $29.4^{\mathrm{aAx}}$ & $30.9^{\mathrm{aAx}}$ & $19.6^{\mathrm{ay}}$ & $17.2^{\mathrm{by}}$ \\
MNFS $(\%, w / w)$ & $60.7^{\mathrm{aA}}$ & $62.5^{\mathrm{aA}}$ & $56.9^{\mathrm{aBy}}$ & $56.2^{\mathrm{aBy}}$ & $62.3^{\mathrm{ax}}$ & $62.4^{\mathrm{ax}}$ \\
S/M $(\%, w / w)$ & $3.39^{\mathrm{aA}}$ & $2.14^{\mathrm{bB}}$ & $3.52^{\mathrm{aAx}}$ & $2.26^{\mathrm{bAx}}$ & $3.11^{\mathrm{ax}}$ & $1.69^{\mathrm{by}}$ \\
FDM $(\%, w / w)$ & $41.06^{\mathrm{bA}}$ & $44.41^{\mathrm{aA}}$ & $22.94^{\mathrm{aBx}}$ & $22.15^{\mathrm{aBx}}$ & $20.68^{\mathrm{ax}}$ & $23.94^{\mathrm{ax}}$ \\
NESP $\left(\mathrm{g} \cdot \mathrm{g}^{-1}\right.$ protein $)$ & $1.45^{\mathrm{aA}}$ & $1.51^{\mathrm{aA}}$ & $1.51^{\mathrm{aAy}}$ & $1.49^{\mathrm{aAy}}$ & $1.82^{\mathrm{ax}}$ & $1.76^{\mathrm{ax}}$ \\
pH & $5.31^{\mathrm{aA}}$ & $5.23^{\mathrm{aB}}$ & $5.20^{\mathrm{aAy}}$ & $5.29^{\mathrm{aAy}}$ & $5.76^{\mathrm{ax}}$ & $5.66^{\mathrm{ax}}$ \\
\hline
\end{tabular}

Cheese code: Treatment cheeses, described in detail in Section 2, included the following: full-fat, full salt (FFFS); full-fat, reduced-salt (FFFS); reduced-fat, full-salt (RFFS); reduced-fat, reduced-salt (RFRS), reducedfat, full-salt with low calcium content (RFFSLCa); and reduced-fat, reduced-salt with low calcium content (RFRSLCa)

Presented data represent the means of three replicate trials for each of the treatment mozzarella cheeses

Abbreviations: $C a$ calcium, $M N F S$ moisture-in-non-fat substances, $S / M$ salt-in-moisture, $F D M$ fat-in-dry matter, NESP non-expressible serum

${ }^{\mathrm{a}, \mathrm{b}}$ Values within a row not sharing a common lowercase superscript differ significantly for the statistical effect of salt content on the full-fat cheeses (FFFS, FFRS), the reduced-fat cheeses (RFFS, RFRS) and reduced-fat cheese with low calcium level (RFFSLCa, RFRSLCa) $(P<0.05)$

${ }^{\mathrm{A}, \mathrm{B}}$ Values within a row not sharing a common uppercase superscript differ significantly for the effect of reducing fat content on the full-salt (FFFS, RFFS) and reduced-salt (FFRS, RFRS), $(P<0.05)$

${ }^{\mathrm{x}, \mathrm{y}}$ Values within a row not sharing a common lowercase superscript differ significantly for the effect of reducing calcium content on the reduced-fat full-salt (RFFS, RFFSLCa) and reduced-fat reduced-salt (RFRS, RFRSLCa) cheeses $(P<0.05)$ 
substances (MNFS). Comparison of corresponding pairs of cheese (FFFS and FFRS, RFFS and RFRS, and RFFSLCa and RFRSLCa) showed that apart from its effect on salt-in-moisture content, reducing salt content had otherwise little impact on the composition of the 7-day-old cheese, probably because of the small difference in salt content between the full-salt and reduced-salt levels ( $\sim 1.8 \%$ versus $1.1 \%)$. However, the FFRS cheese had a higher fat content and lower protein content than the FFFS cheese; this may be due to differences in fat losses during the kneading/stretching process in hot water rather than to the impact of salt per se.

Reducing the calcium content of the RFFS and RFRS cheeses resulted in significant increases in the contents of moisture and MNFS and $\mathrm{pH}$, and a concomitant reduction in level of protein.

\subsection{Proteolysis}

\subsubsection{Urea-polyacrylamide gel electrophoresis (PAGE)}

The urea-PAGE gel electrophoretograms of the six different cheeses applied to the gel on the basis of a fixed weight of protein or a fixed weight of cheese are shown in Figs. 3 and 4 , respectively.

For all cheeses, $\alpha_{\mathrm{s} 1}$-casein was degraded slowly during ripening mainly into $\alpha_{\mathrm{s} 1}$-CN (f24-199), but also to breakdown products of lower, $\alpha_{\mathrm{s} 1}-\mathrm{CN}$ (f102-199), and of higher electrophoretic mobility such as $\alpha \mathrm{s} 1-\mathrm{CN}$ (f121-199), $\alpha_{\mathrm{s} 1-\mathrm{CN}}$ (f33-), $\alpha \mathrm{s} 1-\mathrm{CN}$ (f104199 ), as identified according to Mooney et al. (1998). Comparatively little hydrolysis of $\beta$-casein was noted, even though low intensity bands of $\beta_{3^{-}}, \beta_{2^{-}}$and $\beta_{1}$-caseins and ( $\beta_{1}-\mathrm{CN}$ f1-192) were present at all ripening times at intensities depending on the cheese treatment.

When loading the gel with a fixed weight of cheese (Fig. 3), the electrophoretogram reflects the differences in protein content and its significance in relation to rheology melt characteristics and sensory properties. The levels of intact $\alpha_{\mathrm{s} 1}$-casein and $\beta$-casein in 1-day-old cheeses increased as the fat content was reduced, as indicated by the higher intensity of these bands in the RFFS and RFRS cheeses compared to FFFS and FFRS cheeses. This trend, which is expected because of the inverse relationship between fat and protein content (Table 1), is less evident at later times, especially for $\alpha_{\mathrm{s} 1}$-casein at $\geq 35$ days, owing to differences in the rates of degradation of $\alpha_{\mathrm{s} 1^{-}}$and $\beta$-caseins between the different cheeses.

The extent of proteolysis in the different cheese treatments, without the confounding effect of differences in total protein content due to variation in compositions of the different cheeses, can be seen from the electrophoretogram with a fixed weight of protein (Fig. 3). Reducing the salt content of the full-fat cheese led to a slight increase in the degradation of $\alpha_{\mathrm{s} 1}-\mathrm{CN}$, as reflected by the slightly higher intensities of $\alpha_{\mathrm{s} 1}-\mathrm{CN}$ (f24-199) in the FFRS cheese at 35 and 50 days compared to corresponding FFFS cheese. In agreement with the trend in WSN, salt reduction had no notable effect on the casein breakdown in the RF cheeses (RFFS, RFRS). Reducing salt content resulted in higher levels of $\beta$-CN (f1-192) but otherwise had little impact on the extent or pattern of $\beta$-casein degradation. Reducing the fat content of the 35 and 50-day-old FS and RS cheeses resulted in higher levels of intact $\alpha_{\mathrm{s} 1}-\mathrm{CN}$ and lower concentration of $\alpha_{\mathrm{s} 1}-\mathrm{CN}$ 

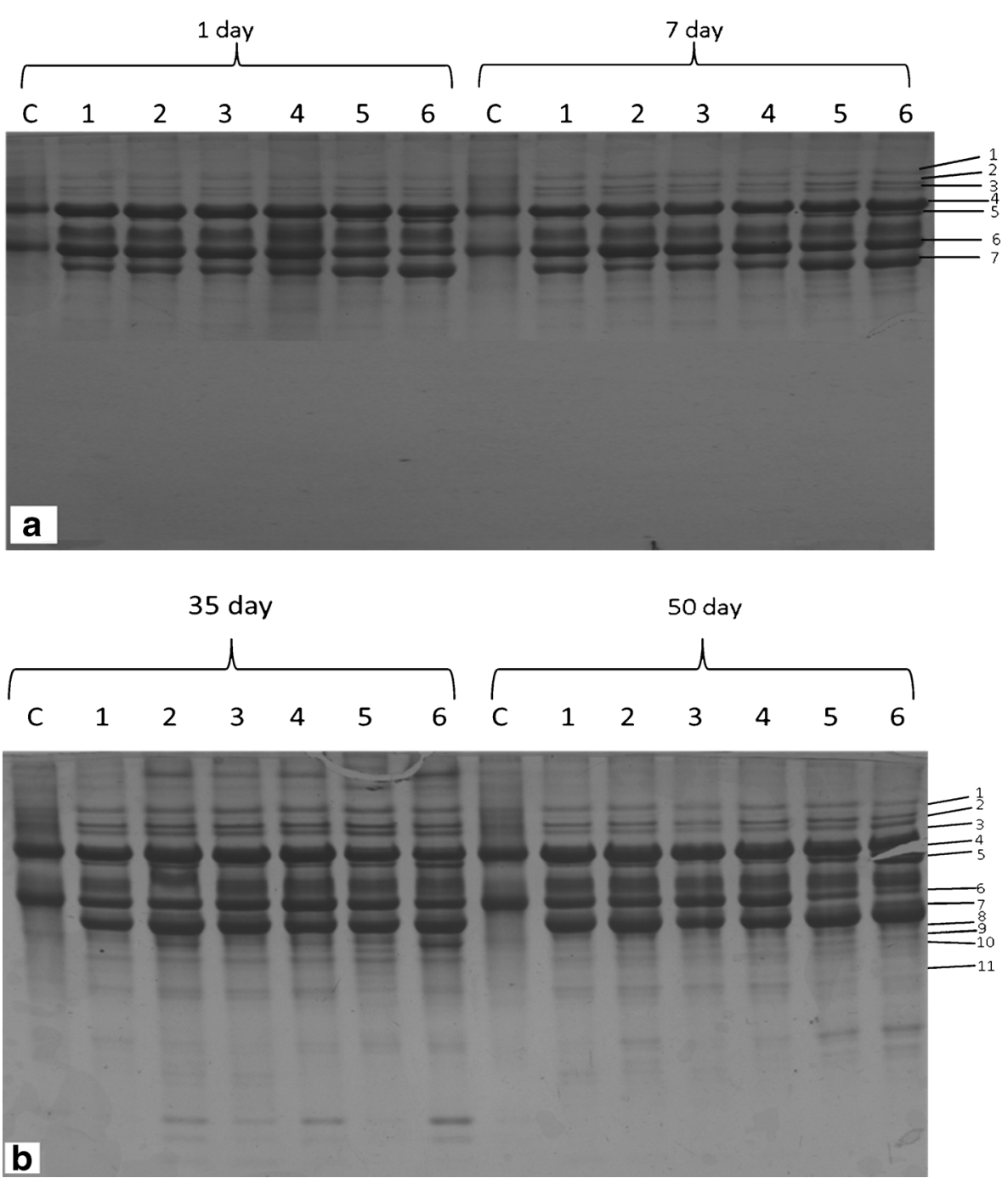

Fig. 3 Urea-polyacrylamide gel electrophoretograms of mozzarella-style cheeses (lanes 1-6) loaded with a fixed weight of protein $\left(4.25 \mathrm{mg}\right.$ protein per lane) after ripening at $4{ }^{\circ} \mathrm{C}$ for 1 or 7 days (a) and for 35 or 50 days (b). The cheeses, defined in Table 1, include: FFFS, lane 1; FFRS, lane 2; RFFS, lane 3; RFRS, lane 4, RFFSLCa, lane 5; and RFRSLCa, lane 6. Sodium caseinate (lane C), loaded at $4.25 \mathrm{mg}$ protein per lane, was used as control, unhydrolyzed casein. Proteins and peptides identified according to Mooney et al. (1998): $1, \beta-\mathrm{CN}(\mathrm{f} 106-209)\left(\gamma_{2}\right) ; 2, \beta-\mathrm{CN}(\mathrm{f} 29-209)\left(\gamma_{1}\right) ; 3, \beta-\mathrm{CN}$ f108-209 $\left(\gamma_{3}\right) ; 4, \beta-\mathrm{CN} ; 5, \beta-\mathrm{CN}$ (f1-192); $6, \alpha_{\mathrm{s} 1}{ }^{-}$ $\mathrm{CN} ; 7, \alpha_{\mathrm{s} 1}-\mathrm{CN}(\mathrm{fl} 102-199) ; 8, \alpha_{\mathrm{s} 1}-\mathrm{CN}$ (f24-199); 9, $\alpha_{\mathrm{s} 1}-\mathrm{CN}$ (f121-199); 10, $\alpha_{\mathrm{s} 1}-\mathrm{CN}$ (f33-*); 11, $\alpha_{\mathrm{s} 1}-\mathrm{CN}$ (f104199)

(f24-199). Reducing the calcium content of the RFFS and RFRS cheeses resulted in notable increases in the degradation of $\alpha_{\mathrm{s} 1}-\mathrm{CN}$ at all times, especially at 50 days where essentially all the native $\alpha_{\mathrm{s} 1}$-CN had been degraded. Similarly, degradation of $\beta$-casein was more extensive in the reduced-calcium cheeses (RFFSLCa, RFRSLCa) at 35 and 50 days, especially in the RFRSLCa in which significant accumulation of the peptide $\beta$-casein (f1-192) occurred. 

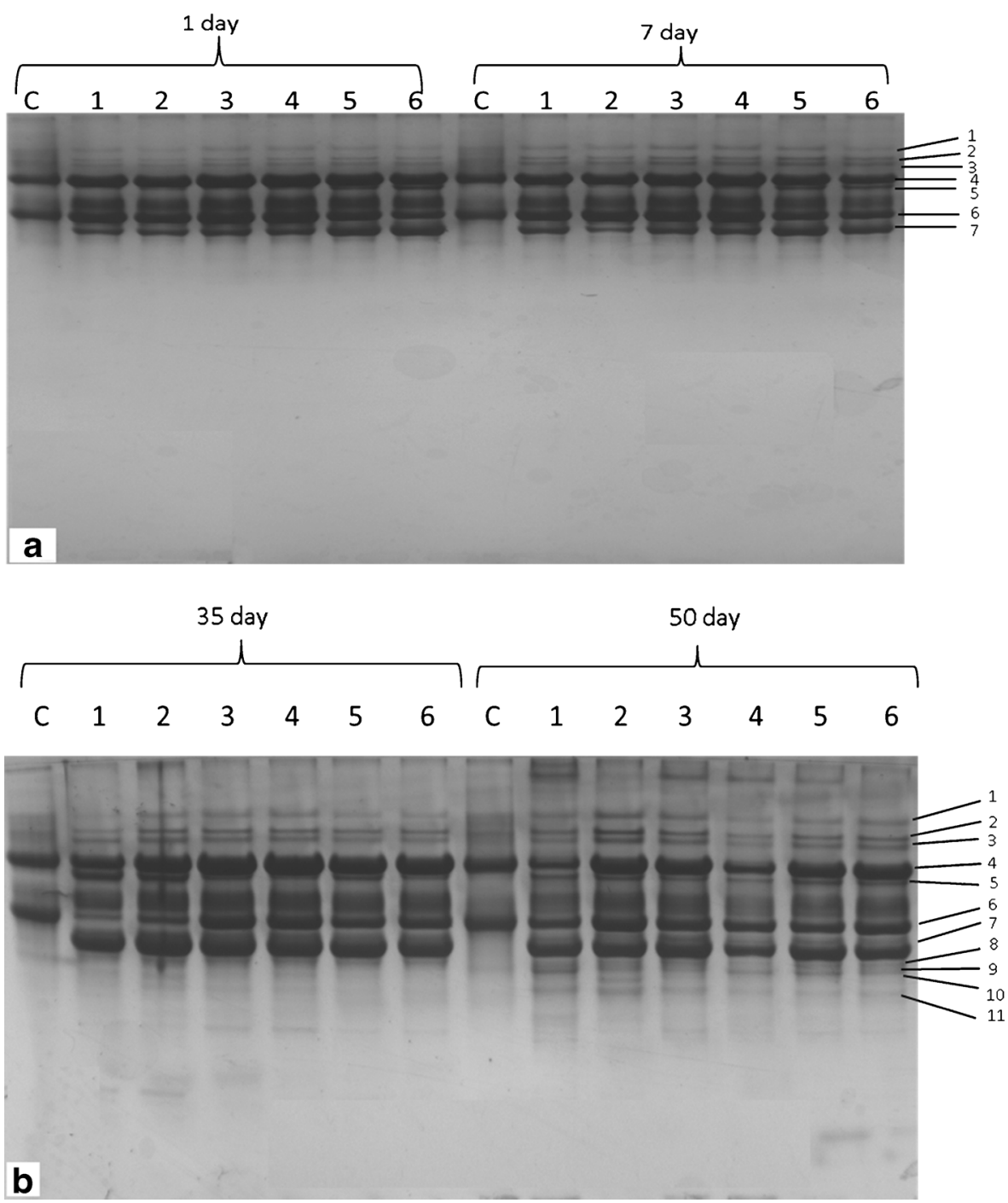

Fig. 4 Urea-polyacrylamide gel electrophoretograms of mozzarella-style cheeses (lanes 1-6) loaded with a fixed weight of cheese (16 mg protein per lane) after ripening at $4{ }^{\circ} \mathrm{C}$ for 1 or 7 days (a) and for 35 or 50 days (b). The cheeses, defined in Table 1, include: FFFS, lane 1; FFRS, lane 2; RFFS, lane 3; RFRS, lane 4; RFFS LCa, lane 5; and RFRSLCa, lane 6. Sodium caseinate (lane C), loaded at $4.25 \mathrm{mg}$ protein per lane, was used as a control unhydrolyzed casein. Proteins and peptides identified according to Mooney et al. (1998): $1, \beta-\mathrm{CN}(f 106-209)(\gamma 2) ; 2, \beta-\mathrm{CN}(f 29-209)(\gamma 1) ; 3, \beta-\mathrm{CN}$ f108-209 $(\gamma 3) ; 4, \beta-\mathrm{CN} ; 5, \beta-$ $\mathrm{CN}$ (f1-192); 6, $\alpha$ s1-CN; 7, $\alpha$ s1-CN (f102-199); 8, $\alpha$ s1-CN (f24-199); 9, $\alpha$ s1-CN (f121-199); 10, $\alpha \mathrm{s} 1-\mathrm{CN}(\mathrm{f33}-*) ; 11, \alpha \mathrm{s} 1-\mathrm{CN}$ (f104-199)

\subsubsection{Water-Soluble Nitrogen}

The level of WSN, which is indicative of the degree hydrolysis of the para-casein by residual chymosin or plasmin, increased in all cheeses during ripening (Fig. 5).

The level of WSN in the FF (FFFS, FFRS) and RF (RFFS, RFRS) cheeses was significantly affected by ripening time, but not by salt content. In contrast, WSN in the 

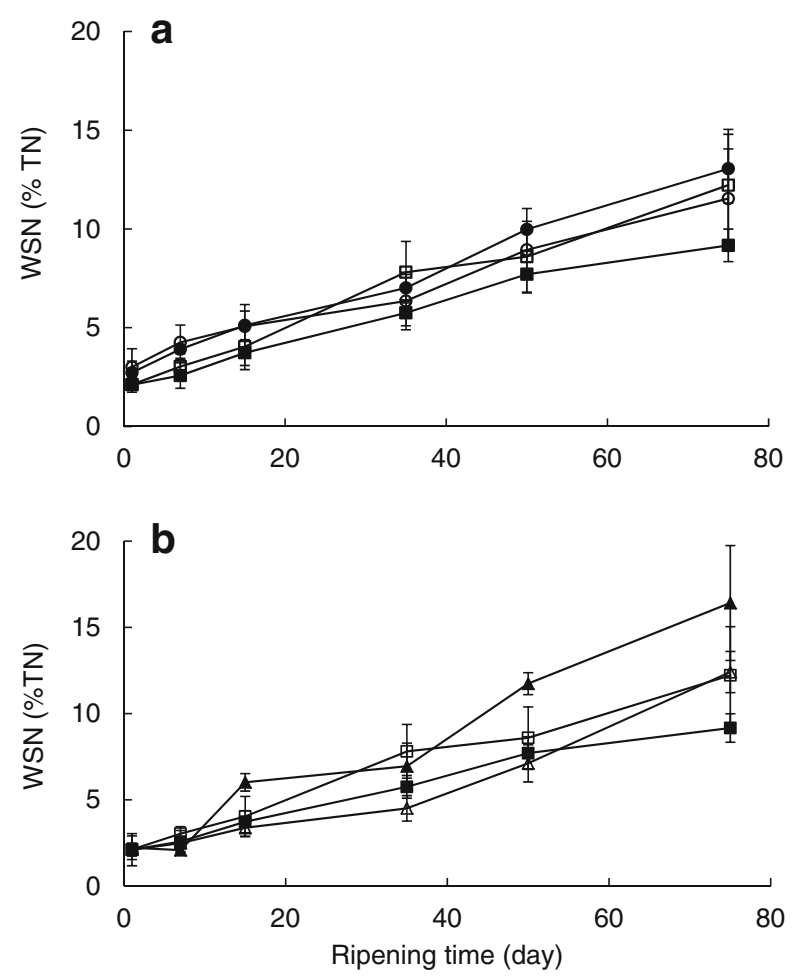

Fig. 5 Changes in WSN in mozzarella cheeses during ripening at $4{ }^{\circ} \mathrm{C}$. The cheeses, defined in Table 1 , include: a full-fat and reduced-fat cheeses with different salt levels: FFFS (filled circle), FFRS (empty circle), RFFS (filled square) and RFRS (empty square); and b reduced-fat cheeses with different salt and calcium levels: RFFS (filled square), RFRS (empty square), RFFSLCa (filled triangle) and RFFSLCa (empty triangle). Presented values are the means of three replicate trials; error bars represent standard deviations of the mean.

RFLCa (RFFS, RFRS) cheese was affected by salt content, with the mean level in the RFRSLCa cheese over the ripening period being significantly lower than that of the RFFSLCa cheese (Table 2).

Reducing fat content significantly decreased the mean level of WSN in the FS cheese over ripening period but did not significantly affect the level in the RS cheese. The latter result however contrasts with urea PAGE which showed less intact $\alpha_{\mathrm{s} 1 \text {-casein }}$ in the RFRS cheese compared to the RFFS cheese.

Calcium reduction significantly increased the mean value of WSN over ripening in the RFFS cheese, but not in the RFRS cheese. Moreover, ANOVA indicated that the mean WSN level in the RFRSLCa cheese over the ripening was significantly higher than that of the RFFS cheese and FFFS cheese.

\subsection{Changes in non-expressible serum}

The level of non-expressible serum (NES), expressed as gramme per gramme of protein (NESP), is an index of the water-holding capacity (WHC) of the cheese (Guo et al. 1997), with higher levels of NESP corresponding to a higher WHC (Guinee et al. 2002). NESP is an important attribute in cheese intended for cooking, as it affects the 


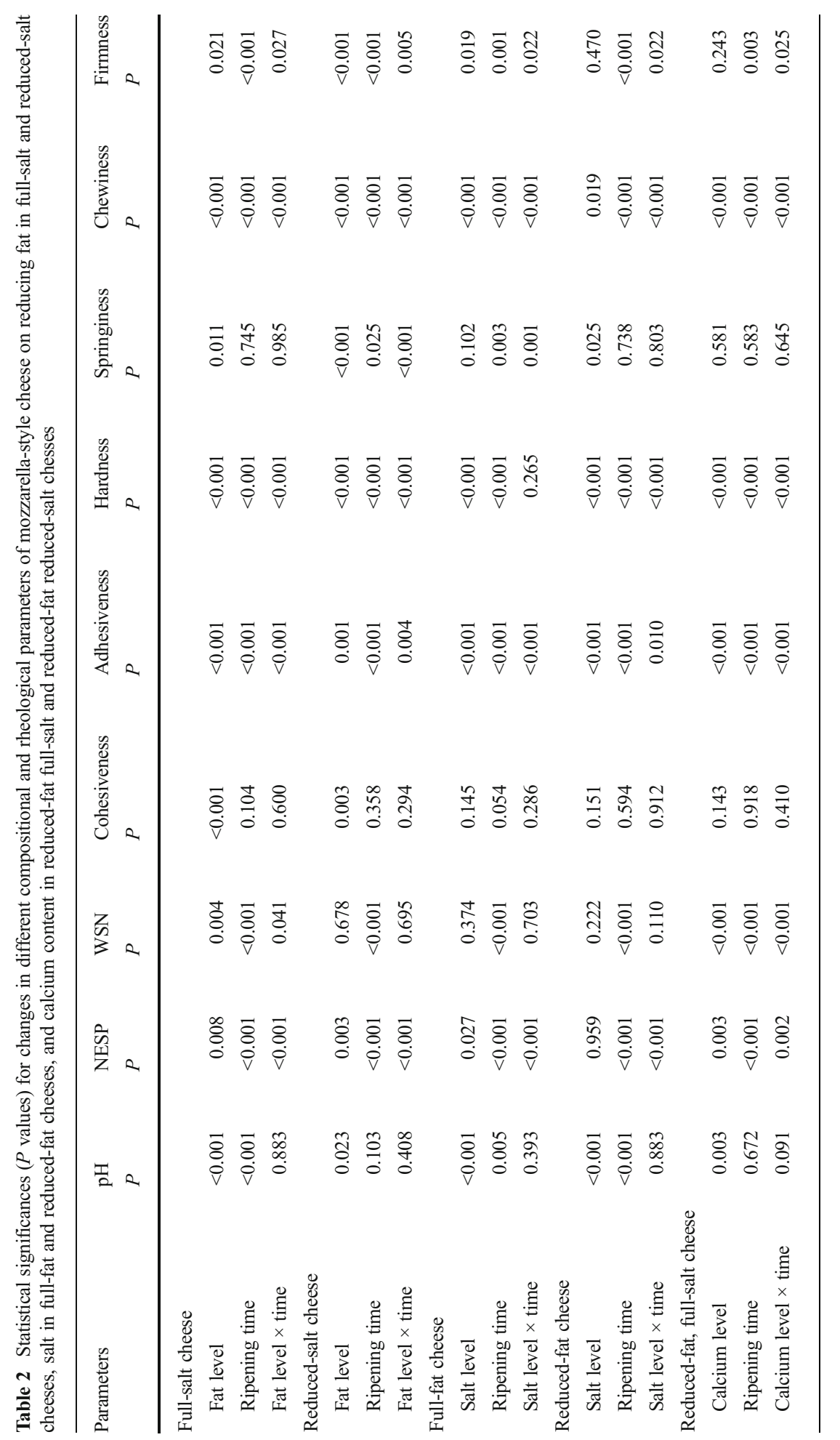




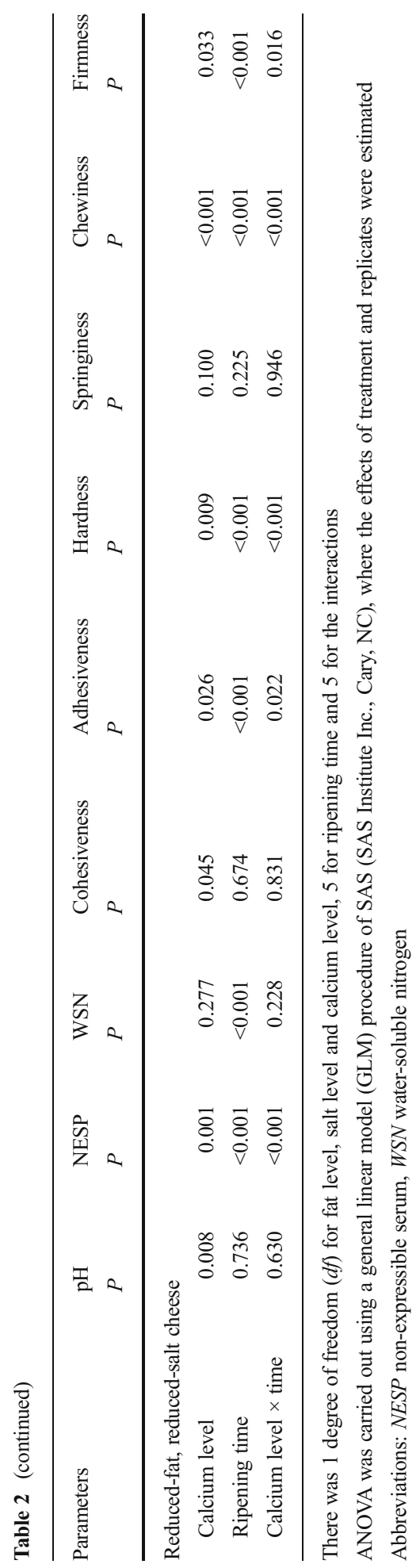


ability of the matrix to retain moisture during heating and, hence, the cooking properties, such as flowability, stretchiness and fluidity (Guo et al. 1997).

The level of NESP in the FF cheeses was significantly affected by salt content, ripening time and interaction of ripening time and salt content, with the mean level over the 75-day ripening period being significantly higher in the FFRS than in the FFFS cheese (Table 2, Fig. 6). Hence, ANOVA of the data at individual ripening times indicated that the levels of NESP in FFFS were lower than those of the FFRS at times $\geq 15$ days. In contrast to the FF cheese, the NESP levels in the RF and RFLCa cheeses were not influenced by salt content but were significantly affected by ripening time and the interaction between ripening time and salt content.

The level of NESP in the FS and RS cheese was significantly affected by fat content and the interaction of fat content and ripening time (Table 2, Fig. 6), with the mean level in the RF variants (RFFS, RFRS) over the 75-day ripening period being significantly lower than that of the corresponding FF variants (FFFS, FFRS). Moreover, ANOVA indicated that the level of NESP in the FFFS cheeses was significantly higher than that in the RFFS cheese at ripening times $\geq 35$ days, while the level in the FFRS were higher than those in the RFRS cheese at times $\geq 15$ days.
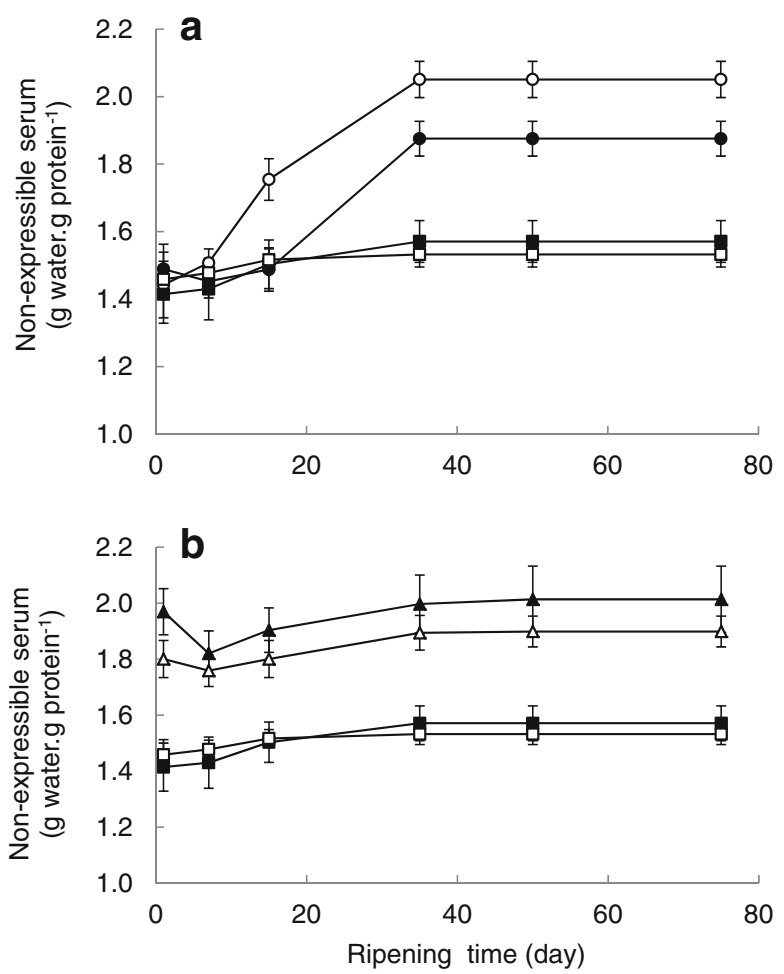

Fig. 6 Changes in levels of non-expressible serum in mozzarella-style cheese during ripening at $4{ }^{\circ} \mathrm{C}$. The cheeses, defined in Table 1, include: a full-fat and reduced-fat cheeses with different salt levels: FFFS (filled circle), FFRS (empty circle), RFFS (filled square) and RFRS (empty square); and b reduced-fat cheeses with different salt and calcium levels: RFFS (filled square), RFRS (empty square), RFFSLCa (filled triangle) and RFFSLCa (empty triangle). Presented values are the means of three replicate trials; error bars represent standard deviations of the mean 
Reducing the calcium content of the RFFS and RFRS cheeses significantly increased the mean level of NESP over the 75-day ripening period and at all ripening times.

\subsection{Rheology and texture profile analysis}

The changes in firmness (force on compression of cheese cube to $30 \%$ original height in a single compression stroke or bite at $8^{\circ} \mathrm{C}$ ) and different texture profile parameters (hardness, adhesiveness, cohesiveness, chewiness and springiness) on $40 \%$ compression in a two-bite test) during ripening are shown in Figs. 7, 8, 9 and 10. None of the cheeses fractured during compression.

The firmness, hardness, chewiness, adhesiveness and cohesiveness in FF and RF cheeses were significantly affected by salt content, ripening time, and, in most cases, by the interaction of salt and ripening time (Table 2). Consistent with the age-related increase in casein hydrolysis, the mean values for all of these parameters decreased significantly in all cheeses during ripening, apart from adhesiveness which increased.
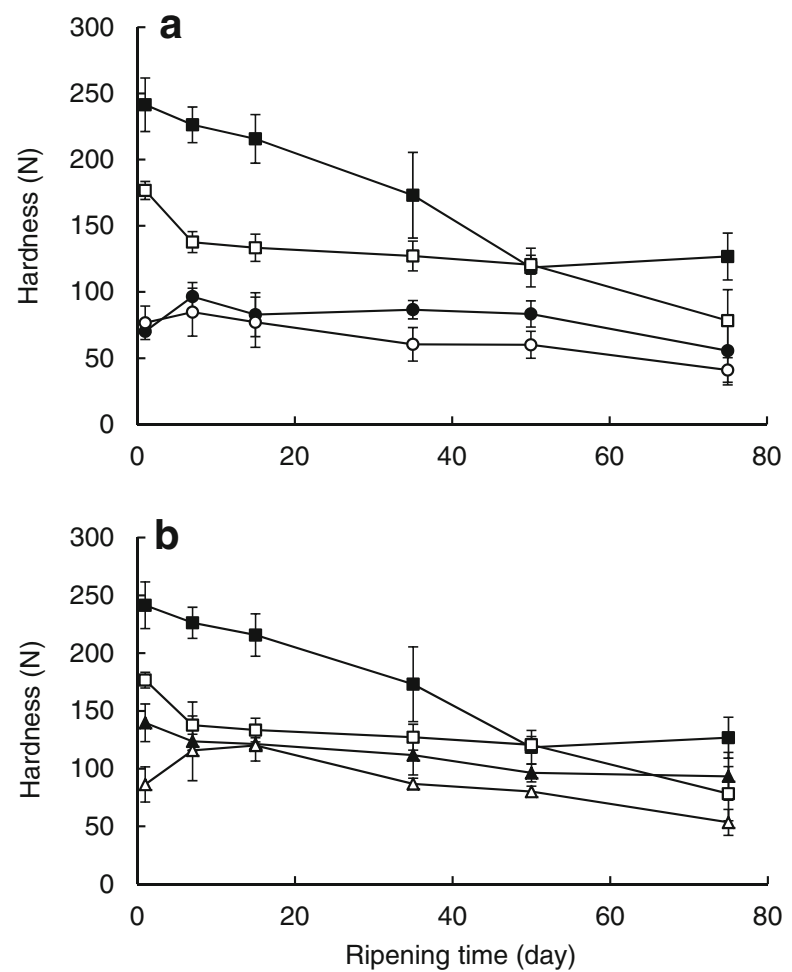

Fig. 7 Changes in hardness in mozzarella cheeses during ripening at $4{ }^{\circ} \mathrm{C}$. The cheeses, defined in Table 1 , include: a full-fat and reduced-fat cheeses with different salt levels: FFFS (filled circle), FFRS (empty circle), RFFS (filled square) and RFRS (empty square); and $\mathbf{b}$ reduced-fat cheeses with different salt and calcium levels: RFFS (filled square), RFRS (empty square), RFFSLCa (filled triangle) and RFFSLCa (empty triangle). Presented values are the means of three replicate trials; error bars represent standard deviations of the mean

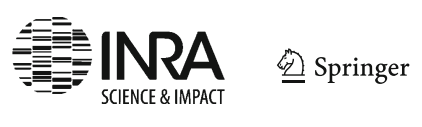



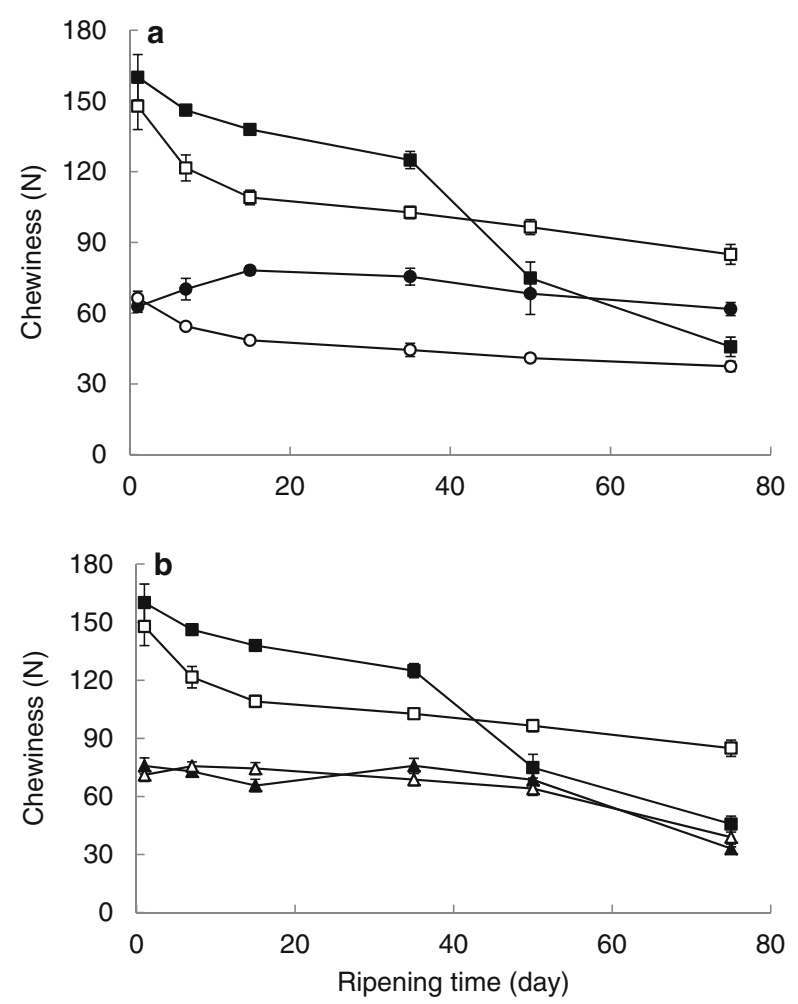

Fig. 8 Changes in chewiness in mozzarella cheeses during ripening at $4{ }^{\circ} \mathrm{C}$. The cheeses, defined in Table 1 , include: a full-fat and reduced-fat cheeses with different salt levels: FFFS (filled circle), FFRS (empty circle), RFFS (filled square) and RFRS (empty square); and b reduced-fat cheeses with different salt and calcium levels: RFFS (filled square), RFRS (empty square), RFFSLCa (filled triangle) and RFFSLCa (empty triangle). Presented values are the means of three replicate trials; error bars represent standard deviations of the mean

Reducing salt content of the full-fat (FFFS) and reduced-fat cheeses (RFFS, RFFS LCa) resulted in significant decreases in the mean values for hardness and chewiness over the 75-day ripening period (Table 2), but did not affect cohesiveness. Conversely, the mean adhesiveness of these cheeses over the ripening period increased with reduction in salt content.

Firmness and all TPA parameters of the full-salt (FS) and reduced-salt (RS) cheeses were significantly affected by fat content and by the interaction of fat content and ripening time in the case of firmness, hardness, adhesiveness and chewiness (Table 2). Reducing fat content significantly increased the mean firmness, hardness, chewiness and cohesiveness of both the FS and RS cheeses over ripening. In contrast to the above, the mean adhesiveness of both the FS and RS cheeses over the ripening period increased significantly as the fat content was reduced (Fig. 9).

Reducing calcium content of the RFFS and RFRS cheeses significantly reduced the mean values for firmness, hardness and chewiness over the 75-day ripening period. In contrast the mean adhesives of the RFFS cheese increased, while that of the RFRS decreased, as the calcium content was reduced. As indicated by the significant 

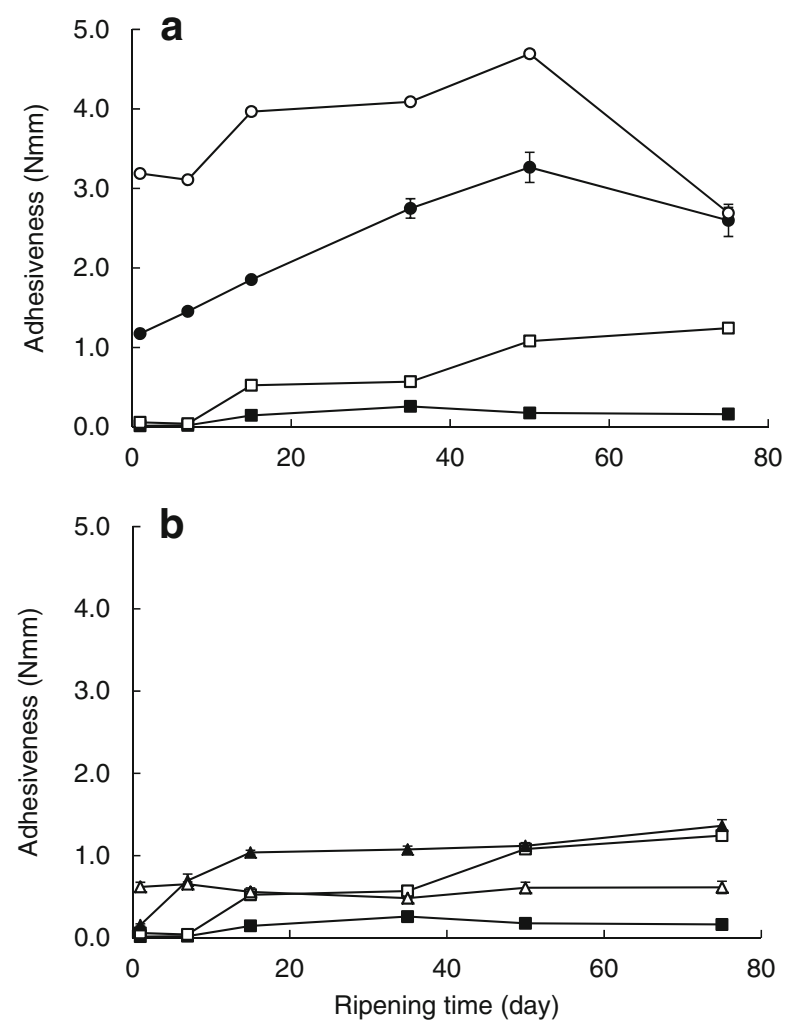

Fig. 9 Changes in adhesiveness in mozzarella cheeses during ripening at $4{ }^{\circ} \mathrm{C}$. The cheeses, defined in Table 1, include: a full-fat and reduced-fat cheeses with different salt levels: FFFS (filled circle), FFRS (empty circle), RFFS (filled square) and RFRS (empty square); and b reduced-fat cheeses with different salt and calcium levels: RFFS (filled square), RFRS (empty square), RFFSLCa (filled triangle) and RFFSLCa (empty triangle). Presented values are the means of three replicate trials; error bars represent standard deviations of the mean

interactive effects between calcium content and ripening time, the response of the above variables to ageing differed depending on calcium level, and on salt content as discussed above (Table 2). Similar to the trend noted for influence of salt content, cohesiveness in both the RFFS and RFRS cheeses was unaffected by calcium level in the range studied.

\subsection{Meltability}

The age-related change in the flowability of the heated cheese was measured using modifications of the Schreiber (Sch-flow, Fig. 11) and Price-Olson (PO-flow, data not shown) methods, as described by Guinee and O'Callaghan (2013). These tests simulate, respectively, the extent of flow or spread of cheese in cooking applications where cheese is exposed to the oven atmosphere (such as pizza and cheese bruschetta), or not exposed, as in closed sandwiches and burgers.

The Sch-flow and PO-flow of the FF and RF cheeses were significantly affected by salt content, by ripening time and by the interaction of salt and ripening time (Table 3). 

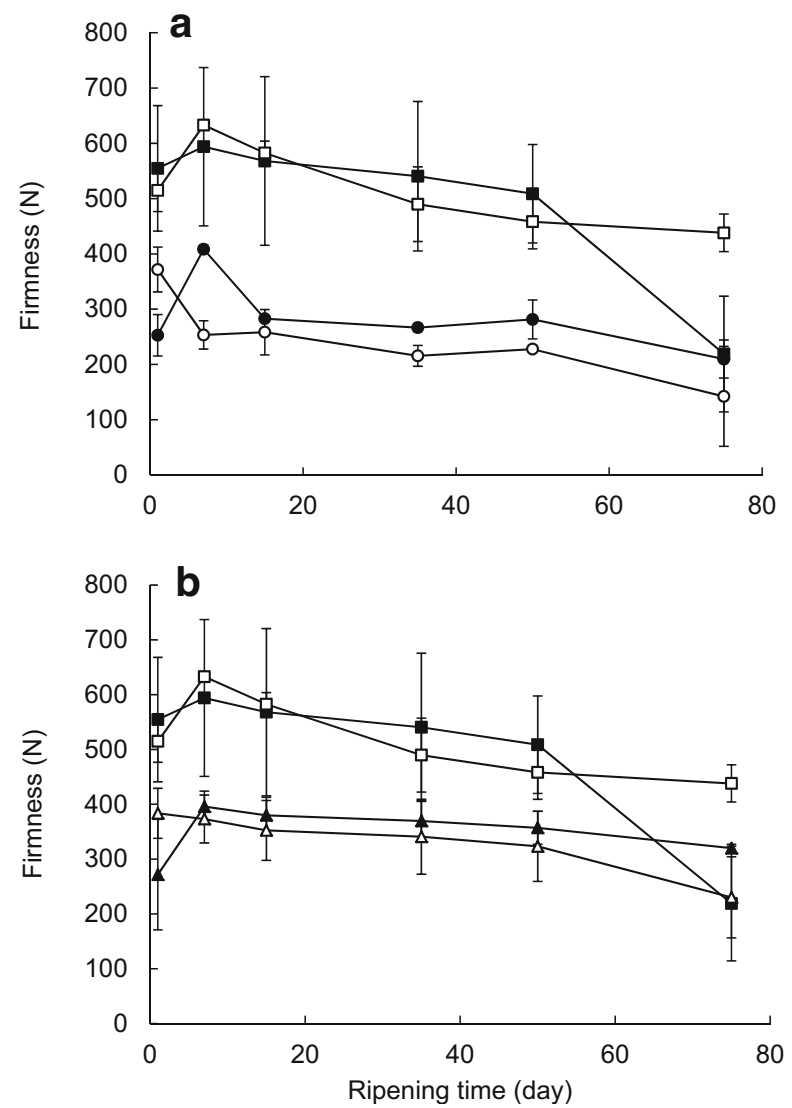

Fig. 10 Changes in firmness in mozzarella cheeses during ripening at $4{ }^{\circ} \mathrm{C}$. The cheeses, defined in Table 1 , include: a full-fat and reduced-fat cheeses with different salt levels: FFFS (filled circle), FFRS (empty circle), RFFS (filled square) and RFRS (empty square); and b reduced-fat cheeses with different salt and calcium levels: RFFS (filled square), RFRS (empty square), RFFSLCa (filled triangle) and RFFSLCa (empty triangle). Presented values are the means of three replicate trials; error bars represent standard deviations of the mean

The flow of all cheese increased significantly during ripening, as the level of proteolysis increased. This increase was generally most pronounced during the first 15 days during which the $\alpha_{\mathrm{s} 1}$-casein was extensively hydrolysed (Fig. 11).

Using both methods, the mean flow of the FF cheese over the 75-day ripening period increased significantly as the salt content was reduced. The difference in flow between the FFFS and FFRS was greatest at 1 day (25\% and 44\%, respectively) and remained essentially constant between 15 and 75 days, at which time the respective flows for the latter cheeses were $55 \%$ and $65 \%$. While a similar trend was noted for the RF cheese, the difference in the magnitude of the means over the 75-day ripening period or the values at any specific ripening time were relatively small, for example $\sim 34 \%$ vs. $37 \%$ at 75 days, and would be of little practical significance (Guinee 2015).

Reducing the fat content of the FS and RS cheeses resulted in notable decreases in the mean flow over the entire ripening period, with the percentage reduction being most 

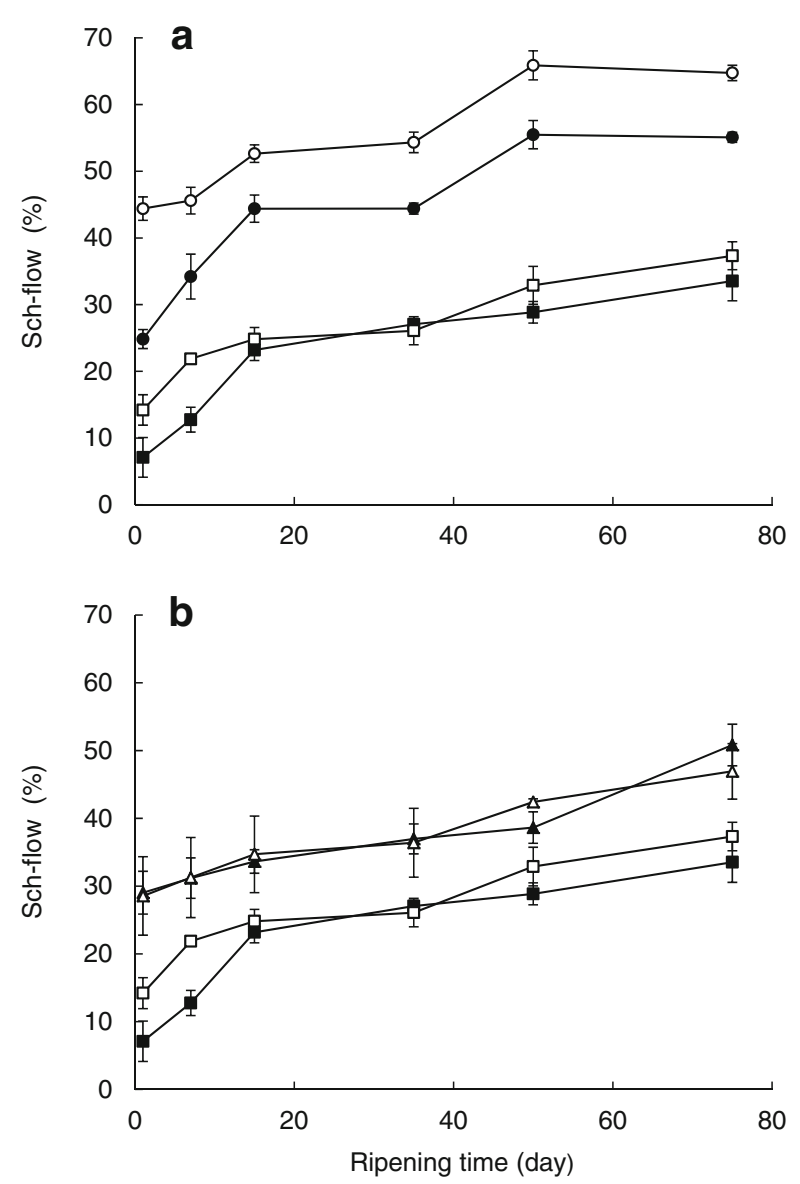

Fig. 11 Changes in Schreiber flow (Sch flow) in mozzarella cheeses during ripening at $4{ }^{\circ} \mathrm{C}$. The cheeses, defined in Table 1, include a full-fat and reduced-fat cheeses with different salt levels: FFFS (filled circle), FFRS (empty circle), RFFS (filled square) and RFRS (empty square); and b reduced-fat cheeses with different salt and calcium levels: RFFS (filled square), RFRS (empty square), RFFSLCa (filled triangle) and RFFSLCa (empty triangle). Presented values are the means of three replicate trials; error bars represent standard deviations of the mean

pronounced for the Sch-flow (49\% and 52\% for the FS and RS, respectively) than for the PO-flow (36\% and 29\% for the FS and RS, respectively). Moreover, ANOVA indicated that the flow at all ripening times (Fig. 11) was significantly lower in the RF cheeses, for example from $\sim 34 \%$ in the RFFS cheese vs. $55 \%$ for the Sch-flow in the FFFS at 75 days.

The Sch-flow and PO-flow of the RFFS and RFRS cheeses was significantly influenced by calcium level and by its interaction with ripening time (Table 3). The mean Sch- and PO-flow of the RFFS and RFRS cheeses over the ripening period increased significantly as the calcium content was reduced (Fig. 11). Despite the increase in flow of the RF cheeses on reducing calcium content, the flow of the RFFSLCa and RFRSLCa cheeses was, nevertheless, notably lower than that of the FFFS and FFRS cheeses at all times. 
Table 3 Statistical significances ( $P$ values) for changes in cooking properties of heated mozzarella-style cheese on reducing fat in full-salt and reduced-salt cheeses, salt in full-fat and reduced-fat cheeses, and calcium content in reduced-fat full-salt and reduced-fat reduced-salt chesses

\begin{tabular}{|c|c|c|c|}
\hline Factor & $\begin{array}{l}\text { Flow-Sch } \\
P\end{array}$ & $\begin{array}{l}\text { Flow-PO } \\
P\end{array}$ & $\begin{array}{l}\text { EW } \\
P\end{array}$ \\
\hline \multicolumn{4}{|l|}{ Full-fat cheese } \\
\hline Salt level & $<0.001$ & 0.007 & $<0.001$ \\
\hline Ripening time & $<0.001$ & $<0.001$ & $<0.001$ \\
\hline Salt level $\times$ time & $<0.001$ & 0.012 & 0.310 \\
\hline \multicolumn{4}{|l|}{ Reduced-fat cheese } \\
\hline Salt level & $<0.001$ & $<0.001$ & $<0.001$ \\
\hline Ripening time & $<0.001$ & $<0.0001$ & $<0.001$ \\
\hline Salt level $\times$ time & 0.005 & 0.021 & $<0.001$ \\
\hline \multicolumn{4}{|l|}{ Full-fat cheese } \\
\hline Fat level & $<0.001$ & $<0.001$ & $<0.001$ \\
\hline Ripening time & $<0.001$ & $<0.001$ & $<0.001$ \\
\hline Fat level $\times$ time & 0.015 & $<0.001$ & 0.011 \\
\hline \multicolumn{4}{|l|}{ Reduced-fat cheese } \\
\hline Fat level & $<0.001$ & $<0.001$ & $<0.001$ \\
\hline Ripening time & $<0.001$ & $<0.001$ & $<0.001$ \\
\hline Fat level $\times$ time & 0.007 & 0.005 & $<0.001$ \\
\hline \multicolumn{4}{|c|}{ Reduced-fat, full-salt cheese } \\
\hline Calcium level & 0.004 & 0.001 & 0.003 \\
\hline Ripening time & $<0.001$ & $<0.001$ & $<0.001$ \\
\hline Calcium level $\times$ time & $<0.001$ & $<0.001$ & 0.235 \\
\hline \multicolumn{4}{|c|}{ Reduced-fat, reduced-salt cheese } \\
\hline Calcium level & 0.025 & 0.006 & 0.001 \\
\hline Ripening time & $<0.001$ & $<0.001$ & $<0.001$ \\
\hline Calcium level $\times$ time & 0.683 & $<0.001$ & 0.212 \\
\hline
\end{tabular}

There was 1 degree of freedom $(d f)$ for fat level, salt level and calcium level, 5 for ripening time (except in the case of EW where there were 2) and 5 for the interactions (except in the case of EW where there was 2)

ANOVA was carried out using a general linear model (GLM) procedure of SAS (SAS Institute Inc., Cary, $\mathrm{NC}$ ), where the effects of treatment and replicates were estimated

Abbreviations: Flow-Sch and Flow-PO denote percentage flow of heated cheese as measured using modified Schreiber and Price-Olson methods, respectively; $E W$ work required for uniaxial extension of the molten cheese by $380 \mathrm{~mm}$

\subsection{Energy required extend/stretch (EW)}

The work required to uniaxially extend (EW) the molten cheese was measured as an indicator of the toughness of the melted mozzarella on pizza. The EW of the molten FF and RF cheeses was significantly affected by salt content, by ripening time and by the interaction of salt and ripening time in the case of the latter (Fig. 12; Table 3). The mean EW of the RS cheeses over the ripening period was lower than that of the corresponding FS 

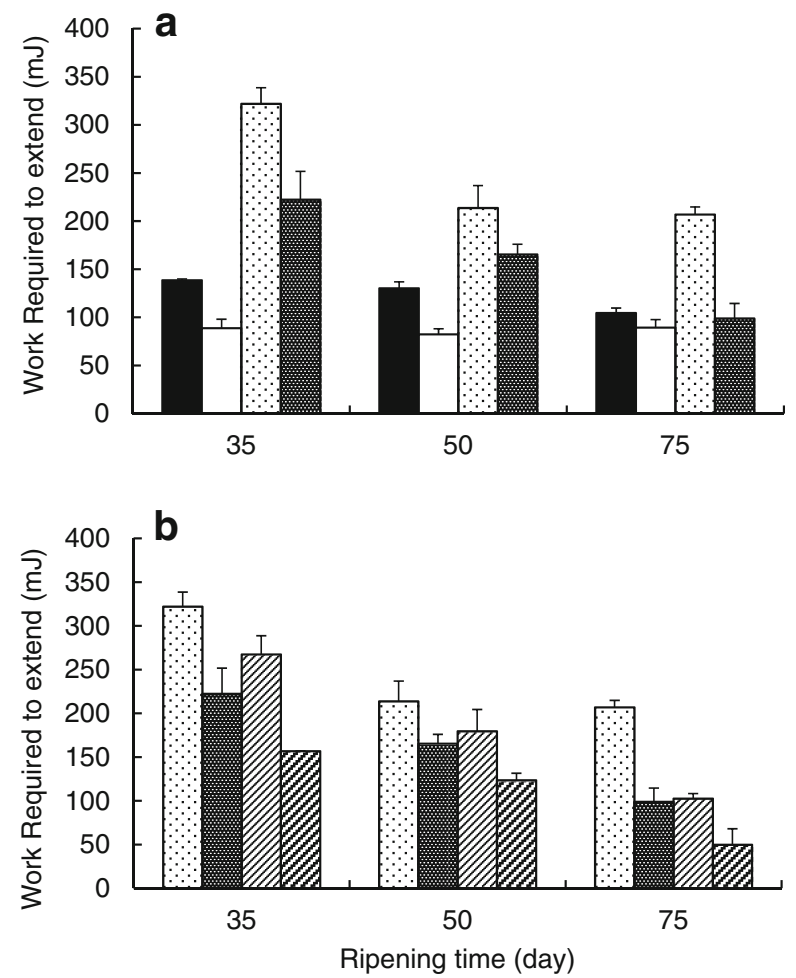

Fig. 12 Changes in EW (work required to uniaxially extend molten cheese by $380 \mathrm{~mm}$ ) in mozzarella cheeses during ripening at $4{ }^{\circ} \mathrm{C}$. The cheeses, defined in Table 1 , include a full-fat and reduced-fat cheeses with

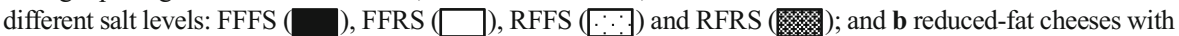
different salt and calcium levels: RFFS ( $\because)$, RFRS ( values are the means of three replicate trials; error bars represent standard deviations of the mean

cheeses. The EW of all cheeses, apart from the FFRS cheese, decreased significantly between 35 and 75 days, with the percentage decrease being highest for the reduced-fat cheeses.

The EW of the full-salt (FS) and reduced-salt (RS) cheeses were significantly affected by fat content, and by the interaction of fat content and ripening time (Table 2). Reducing the fat content significantly increased the mean EW of both the FS and RS cheeses over ripening, with the difference between FF and RF variants diminishing as ripening time progressed.

The EW of the reduced-fat cheeses was significantly influenced by calcium level, with the mean EW for the RFFSLCa and the RFRSLCa over the ripening period being lower than those of the RFFS and RFRS cheeses. However, the magnitude of the calcium effect on EW was small compared to the effect of fat. Hence, the mean EW of the RFFSLCa or RFRSLCa cheeses over the ripening period was significantly higher than that of the corresponding FFFS and FFRS cheeses. Nevertheless, the difference between the above cheeses (RFFSLCa vs RFFS, and RFRSLCa vs FFRS) diminished between 35 and 75 days, at which time the EW of all four cheeses were similar. In contrast, the EW of the RFFS and RFRS were significantly higher than that of the FFFS and FFRS at all ripening times. 


\section{Discussion}

Consistent with earlier studies for cheddar (Guinee et al. 2000) and mozzarella (Rudan et al. 1999; Paulson et al. 1998), reducing fat content resulted in a higher level of protein and lower content of MNFS. However, reducing the calcium content of reduced-fat cheese resulted in a significant increase in the content of MNFS, and reduction in both the level of protein and calcium-to-protein ratio. The latter effects, which concur with those reported by others for mozzarella (Guinee et al. 2002; Upreti et al. 2006), are consistent with a higher degree of casein hydration (Table 1, Fig. 6), which in model systems has been found to be inversely correlated to casein bound calcium (Carr et al. 2002). The general absence of an effect of salt content on composition supports the findings of Paulson et al. (1998) whose data show no relationship between salt content and moisture or MNFS of non-fat mozzarella, in the range $0.14-2.18 \%$ salt. However, it is at variance with studies on cheddar cheese (Rulikowska et al. 2013) which reported that moisture content decreased on average by $\sim 0.14 \%$ per $0.1 \%$ increase in salt content in the range $0.14 \%$ to $2.0 \%$.

The level of primary proteolysis in the control FFFS cheese (WSN $\sim 10$ $12 \mathrm{~g} .100 \mathrm{~g}^{-1}$ of total $\mathrm{N}$ at $45-60$ days), as monitored using urea-PAGE and level of WSN, is typical of that previously reported for mozzarella stored at 4 or $8{ }^{\circ} \mathrm{C}$ (Rudan et al. 1999; Feeney et al. 2001). The increase in proteolysis during ageing was affected by fat content, with fat reduction leading to a slower rate of degradation of $\alpha_{\mathrm{s} 1}$ casein and development of WSN in the full-salt cheese, and salt reduction. The breakdown of $\alpha_{\mathrm{s} 1}$ casein was inhibited by fat reduction, and accelerated by reduction in calcium level and, to a lesser extent, salt. Moreover, reduction in calcium level resulted in more extensive degradation of $\beta$-casein to $\beta$-casein (f1-192). These trends reflect the findings of previous studies for the effects of reducing fat (Rudan et al. 1999; Fenelon and Guinee 2000), salt (Rulikowska et al. 2013) and calcium (Feeney et al. 2002) in various cheeses including cheddar and mozzarella.

The level of NESP in all cheeses during maturation, reflecting an enhanced waterbinding capacity of the protein (Guo et al. 1997; Guinee et al. 2002; Metzger et al. 2001; McMahon et al. 1999; Paulson et al. 1998), probably as a consequence of solubilisation of calcium phosphate (O'Mahony et al. 2006) and protein hydrolysis (Guo et al. 1997). The reduction in NESP as fat level was reduced concurs with the reduction in MNFS content, and may reflect a higher degree of casein aggregation in the reduced-fat cheese. The level of NESP was not influenced by the altering salt content, except in the FF cheese where the mean level over the 75 day ripening period increased as salt level was reduced. This trend differs from that reported by Paulson et al. (1998) who found that ES in non-fat mozzarella decreased as the salt and salt-inmoisture levels in non-fat mozzarella were increased from $0.14 \%$ to $0.85 \%$, and $0.23 \%$ to $1.40 \%$, respectively. The inter-study differences may relate to differences in composition, especially factors that affect protein hydration such as protein-to-moisture ratio and calcium-to-casein ratio (Strange et al. 1994; Bouchoux et al. 2009); the calcium-toprotein ratio of the RF cheeses in the current study (29-31 mg.g in the RF cheeses and $17-20 \mathrm{mg} \cdot \mathrm{g}^{-1}$ in the RFLC cheeses) was notably higher than that $\left(12-13 \mathrm{mg} \cdot \mathrm{g}^{-1}\right)$ in Paulson et al. (1998). The large increase in NESP in the RF cheese on reducing the calcium content is commensurate with the decrease in the extent of casein crosslinking by calcium (e.g. attached to phosphoserine groups and acidic amino acid residues) and 
the inverse relationship between the hydration of casein and para-casein and calcium content in model dilute protein dispersions (Creamer 1985; Carr et al. 2002). Hence, a similar trend has been reported previously for mozzarella (Guinee et al. 2002).

The firmness, hardness and chewiness generally decreased, while adhesiveness increased, to varying degrees during ripening depending on levels of fat, salt and calcium. Similar trends for the effect of maturation have been reported for firmness and hardness in mozzarella (Yun et al. 1993) and other internal bacterial ripened cheeses such as cheddar and Gouda which do not undergo moisture loss during maturation (Creamer and Olson 1982; Fenelon and Guinee 2000). This trend is expected as the latter parameters are indices of the stress-bearing capacity of the casein network, which is attenuated by the decrease in the content of intact casein and by hydration of the protein strands and the attendant increase in the ratio of viscous-toelastic character. In contrast, adhesiveness, a measure of work necessary to overcome the attractive forces between the cheese and compression plate (O'Callaghan and Guinee 2004), generally increased during ripening, a trend that is consistent with the increase in the hydration which is expected to reduce the cohesive (attractive) forces with the calcium phosphate para-casein network. Reducing salt content had a similar, though smaller, effect to ageing, i.e. lower firmness, hardness and chewiness, and higher adhesiveness. Chevanan et al. (2006) found that the response of hardness, chewiness and adhesiveness to salt level in cheddar cheese depended on concentrations of lactose and calcium phosphate; a trend similar to that of current study was noted in cheddar denoted as 'high calcium phosphate and high lactose'. Reducing calcium content had similar, but notably larger effects than salt, namely reductions in firmness and chewiness, an increase in adhesiveness, and no effect on cohesiveness. Similar trends were reported by (Chevanan et al. 2006) for hardness and adhesiveness and may be attributed to a lower degree of calcium cross-linking of the casein strands and the concomitant increase in casein hydration in the reduced-calcium cheeses (Guinee et al. 2002). However, the current results contrasted with those of Chevanan et al. (2006) who found that lowering calcium content significantly reduced cohesiveness to an extent influenced by levels of lactose and salt-in-moisture. The interstudy differences in relation to the latter parameter may be associated with differences in the type of cheese (mozzarella and cheddar), fat and moisture content of cheese, and the levels of salt content and calcium-to-casein ratio which varied from $2.5 \%$ to $1.7 \%$ and 26.2 to $20.6 \mathrm{mg} \cdot \mathrm{g}^{-1}$ protein in the study of Chevanan et al. (2006) compared to $1.7 \%$ to $1.0 \%$ and 30.9 to $17.2 \mathrm{mg}^{-1}$ protein in the current study.

In contrast to the effects of ageing, reducing fat content significantly increased the mean firmness, hardness, chewiness and cohesiveness of both full-salt and reduced-salt cheeses over ripening. This trend, which concurs with the findings of Rudan et al. (1999) and Drake et al. (1999), is consistent with the higher concentration of intact protein and, hence, volume fraction of casein network in the reduced-fat cheeses (Guinee 2015). Hence, as a corollary adhesiveness decreased as the fat content was reduced in full-salt and reduced-salt cheeses because of the concomitant reductions in the levels of MNFS and casein hydration.

The heat-induced flow of all cheeses increased during ageing. This trend, which has been extensively reported for various cheese types including mozzarella and cheddar, has been attributed to the reduction in intact casein content, solubilisation of calcium 
and increases in casein hydration (Guo et al. 1997; Guinee et al. 2000). Similarly, the flow was increased by reduction in the levels of salt or calcium level. Similar trends were reported for the effect of salt by Ma et al. (2013) and for calcium by Pastorino et al. (2003) and O'Mahony et al. (2006). This effect, more pronounced with calcium, is likely to be associated with attenuation of the casein network by greater hydrolysis of the casein on reducing salt and by the reduction in the concentration of calciuminduced crosslinking on reducing calcium content (Guinee 2015). In contrast to the effects of reducing salt or calcium level, fat reduction significantly reduced the flow of FS and RS cheeses. This trend corroborates the findings of previous studies (Rudan et al. 1999; Guinee et al. 2000), and is associated with a strengthening of the cheese matrix, due to the attendant increase in the volume fraction of the casein network, the reduction in the lubrication effect of fat and protective effect of free oil in suppressing moisture evaporation from the melting cheese surface (Rudan et al. 1998; Guinee 2015).

The EW of the molten mozzarella decreased with ripening time and with reduction in calcium content. The effects of ripening time and calcium are consistent with the associated increase in casein hydrolysis and decreases in the levels of intact casein (Addeo and Masi 1992; Ak and Gunasekaran 1995) and degree of casein crosslinking which would attenuate the tensile strength of the para-casein fibres. Hence, as a corollary, the increase in casein concentration with fat reduction coincided with an increase in the mean EW of the FS and RS cheeses. Reducing salt content led to a significant decrease in the mean EW of the RF cheese but not in the FF cheese. A tentative explanation for this effect is a concentration-dependent, salt-induced change in ultrastructure (Paulson et al. 1998).

\section{Conclusion}

Simultaneous reduction of fat from $\sim 22 \%$ to $11 \%$ and salt from $1.7 \%$ to $1.0 \%$ in mozzarella cheese resulted in higher levels of moisture and protein, and lower levels of MNFS, FDM and SM. Compared to the FFFS cheese, the RFRS cheese had lower mean levels of non-expressible serum, WSN, adhesiveness, heat-induced-flowability and higher mean levels of firmness, hardness, chewiness, cohesiveness and EW over the 75-day ripening period. These effects, apart from salt-in-moisture content, were mainly due to the effect of fat. While salt reduction reduced firmness and chewiness and increased the mean adhesiveness of the FF cheese (and in some cases the RF cheese) over the 75-day ripening period, the magnitude of the changes caused by reducing salt level was notably smaller than that affected by reducing fat content. Reducing the calcium content of the RFRS cheese by $\sim 50 \%$, from $\sim 1,000$ to $506 \mathrm{mg} .100 \mathrm{~g}^{-1}$ by pre-acidification of the cheese milk, significantly increased the level of moisture, MNFS and NESP, and reduced the protein content and calcium-to-casein ratio. These changes counteracted the adverse effects of fat reduction to greater or lesser degrees by reducing its calcium-to-casein ratio from $\sim 30$ to $17 \mathrm{mg} .100 \mathrm{~g}^{-1}$. Nevertheless, the RFRSLCa cheese was firmer, harder, more cohesive, gummy and chewy, less adhesive, and flowed less and required greater energy to extend on heating compared to the FFFS or FFRS cheese. 
Acknowledgments The research leading to these results has received funding from the European Union's Seventh Framework Programme (FP7/2007-2013) under grant agreement KBBE-2011-5-289536 (PLEASURE).

\section{References}

Addeo F, Masi P (1992) Production of pasta filata cheese. 3rd cheese Symposium National Dairy Products Research Centre, Moorepark. Teagasc, Oak Park, Carlow Ireland. 30-40

Ak MM, Gunasekaran S (1995) Evaluating rheological properties of Mozzarella cheese by the squeezing flow method. J Texture Stud 26:695-711

Bouchoux A, Cayemitte PE, Jardin J, Gesan-Guiziou G (2009) Casein micelle dispersions under osmotic stress. Biophys J 96:693-706

Carr AJ, Munro PA, Campanella OH (2002) Effect of added monovalent cations on the rheology of sodium caseinate solutions. Int Dairy J 12:487-492

CFR (2014) Code of Federal Regulations Part 133. Cheese and related products. Food and Drugs 21 - Code of Federal Regulations, Parts 100-169. US Government Printing Office, Washington

Chevanan N, Muthukumarappan K, Upreti P, Metzger M (2006) Effect of calcium and phosphorous, residual lactose and salt to moisture ratio on textural properties of cheddar cheese during ripening. J Texture Stud 37(6):711-730

Creamer LK (1985) Water absorption by renneted casein micelles. Milchwissenschaft 40:589-591

Creamer LK, Olson NF (1982) Rheological evaluation of maturing cheddar cheese. J Food Sci 47(631-636): 646

Drake MA, Truong VD, Daubert CR (1999) Rheological and sensory properties of reduced-fat processed cheese containing lecithin. J Food Sci 64:744-747

Drewnowski A, Rehm CD (2013) Energy intakes of US children and adults by food purchase location and specific food source. Nutrients 5:1840-1855

Feeney EP, Fox PF, Guinee TP (2001) Effect of ripening temperature on the quality of low-moisture mozzarella cheese: 1. Composition and proteolysis. Lait 81:463-474

Feeney EP, Fox PF, Guinee TP (2002) Effect of pH and calcium concentration on proteolysis in mozzarella cheese. J Dairy Sci 85:1646-1654

Fenelon MA, Guinee TP (2000) Primary proteolysis and textural changes during ripening in cheddar cheeses manufactured to different fat contents. Int Dairy J 10:151-158

Guinee TP (2015) Protein in cheese products: structure-function relationships. In: Advanced Dairy Chemistry, vol. 1 Proteins 4th edn. Part B, P.L.H. McSweeney and S.A. O’Mahony. Springer Publishers, New York (In Press).

Guinee P, O'Callaghan DJ (2013) Effect of increasing the protein-to-fat ratio and reducing fat content on the chemical and physical properties of processed cheese product. J Dairy Sci 96:6830-6839

Guinee TP, Auty MAE, Fenelon MA (2000) The effect of fat content on the rheology, microstructure, and heat-induced functional characteristics of cheddar cheese. Int Dairy J 10:277-288

Guinee TP, Feeney EP, Auty MAE, Fox PF (2002) Effect of pH and calcium concentration on some textural and functional properties of mozzarella cheese. J Dairy Sci 85:1655-1669

Guo MR, Gilmore JA, Kinstedt PS (1997) Effect of sodium chloride on the serum phase of mozzarella cheese. J Dairy Sci 80:3092-3098

He FJ, MacGregor GA (2009) A comprehensive review on salt and health and current experience of worldwide salt reduction programmes. J Hum Hypertens 23:363-384

Hynum R (2014) The 2015 Pizza Power Report. PMQ Pizza magazine. http://www.pmq.com/December2014/Pizza-PowerThe-2015-Pizza-Power-Report/

International Dairy Federation (1993) Milk: determination of the nitrogen content (Kjeldahl method) and calculation of crude protein content. IDF Standard 20B. International Dairy Federation, Brussels, Belgium.

Ma X, James B, Balaban MO, Zhang L, Emanuelsson-Patterson EAC (2013) Quantifying blistering and browning properties of mozzarella cheese. Part II: cheese with different salt and moisture contents. Food Res Int 54:917-921

McMahon DJ, Fife RL, Oberg CJ (1999) Water partitioning in mozzarella cheese and its relationship to cheese meltability. J Dairy Sci 82:1361-1369

Metzger LE, Barbano DM, Kindstedt PS, Guo MR (2001) Effect of milk preacidification on low-fat mozzarella cheese. II. Chemical and functional properties during storage. J Dairy Sci 8:1348-1356

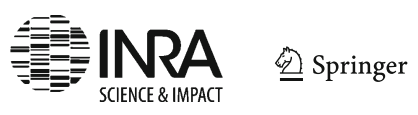


Mooney JS, Fox PF, Healy A, Leaver J (1998) Identification of the principal water-insoluble peptides in cheddar cheese. Int Dairy J 8:813-818

Moshfegh EJ, Holden JM, Cogswell ME, Kuklina EV, Patel SM, Gunn JP, Gillespie C, Hong Y, Merritt R, Galuska DA (2012) Vital Signs: Food categories contributing the most to sodium consumption-United States 20072008. Centers for Disease Control and Prevention. MMWR Morb Mortal Wkly Rep 61(05):92-98

Nickle MS, Pehrsson PR (2013) USDA Updates nutrient values for fast food pizza. Procedia Food Sci 2:8792

O'Callaghan DJ, Guinee TP (2004) Rheology and texture of cheese. In: Fox PF, McSweeney PLH, Cogan TM, Guinee TP (eds) Cheese: Chemistry, Physics and Microbiology, 3rd edition, volume 1-general aspects. Elsevier Ltd, London, pp 511-540

O'Mahony JA, McSweeney PLH, Lucey JA (2006) A model system for studying the effects of colloidal calcium phosphate concentration on the rheological properties of cheddar cheese. J Dairy Sci 89:892-904

Pastorino AJ, Hansen CL, McMahon DJ (2003) Effect of salt on structure-function relationships of cheese. J Dairy Sci 86:60-69

Paulson BM, McMahon DJ, Oberg CJ (1998) Influence of sodium chloride on appearance, functionality and protein arrangements in nonfat mozzarella cheese. J Dairy Sci 81:2053-2064

Powell LM, Nguyen BT, Dietz WH (2015) Energy and nutrient intake from pizza in the United States. Pediatrics. doi:10.1542/peds.2014-1844

Rhodes DG, Adler ME, Clemens JC, LaComb RP, Moshfegh AJ (2014) Consumption of pizza. U.S. Department of Agriculture, Agricultural Research Service, Beltsville Human Nutrition Research Center, Beltsville, MD. Available online at: www.ars.usda.gov/ba/bhnrc/fsrg

Rudan MA, Barbano DM, Guo MR, Kindstedt PS (1998) Effect of modification of fat particle size by homogenization on composition, proteolysis, functionality, and appearance of reduced-fat mozzarella cheese. J Dairy Sci 82:661-672

Rudan MA, Barbano DM, Yun JJ, Kindstedt PS (1999) Effect of fat reduction on chemical composition, proteolysis, functionality and yield of mozzarella cheese. J Dairy Sci 82:661-672

Rulikowska A, Kilcawley KN, Doolan IA, Alonso-Gomez M, Nongonierma AB, Hannon JA, Wilkinson MG (2013) The impact of reduced sodium chloride content on cheddar cheese quality. Int Dairy J 28:45-55

Rynne NM, Beresford TP, Kelly AL, Guinee TP (2004) Effect of milk pasteurization temperature and in situ whey protein denaturation on the composition, texture and heat-induced functionality of half-fat cheddar cheese. Int Dairy J 14:989-1001

SAS Institute (2004) SAS user's guide: Statistics. Version 9, 12th edn. SAS Inst, Inc, Cary

Statista (2015) Mozzarella production in the U.S. 2004-2012. The Statistics Portal. http://www.statista.com/

Strange ED, Van Hekken DL, Holsinger VH (1994) Effect of sodium chloride on the solubility of caseins. J Dairy Sci 77:1216-1222

Tunick MH, Malin EL, Smith PW, Shieh JJ, Sullivan BC, Mackey KL, Holsinger VH (1993) Proteolysis and rheology of low-fat and full-fat mozzarella cheeses prepared from homogenized milk. J Dairy Sci 76 : 3621-3628

Upreti P, Metzger LE, Hayes KD (2006) Influence of calcium and phosphorus, lactose, and salt-to-moisture ratio on cheddar cheese quality: proteolysis during ripening. J Dairy Sci 89:444 453

van Hekken DL, Tunick MH, Malin EL, Holsinger VH (2007) Rheology and melt characteristics of low-fat and full fat mozzarella cheese made from microfluidized milk. LWT Food Sci Technol 40:89-98

Yun JJ, Kiely LJ, Kindstedt PS, Barbano DM (1993) Mozzarella cheese: impact of coagulant type on functional properties. J Dairy Sci 76:3657-3663 